\title{
Geothermal and Mineralogic Analysis of Hot Springs in the Puracé-La Mina Sector in Cauca, Colombia
}

\author{
Darwin Augusto Torres-Ceron (D), ${ }^{1}$ Carlos Daniel Acosta-Medina, ${ }^{2}$ \\ and Elisabeth Restrepo-Parra ${ }^{1}$ \\ ${ }^{1}$ Laboratorio de Física del Plasma, Universidad Nacional de Colombia, Manizales, Colombia \\ ${ }^{2}$ Departamento de Matemáticas y Estadística, Universidad Nacional de Colombia, Manizales, Colombia \\ Correspondence should be addressed to Darwin Augusto Torres-Ceron; dtorresce@unal.edu.co
}

Received 15 June 2018; Revised 13 September 2018; Accepted 8 November 2018; Published 27 February 2019

Guest Editor: Francesco Perri

Copyright (c) 2019 Darwin Augusto Torres-Ceron et al. This is an open access article distributed under the Creative Commons Attribution License, which permits unrestricted use, distribution, and reproduction in any medium, provided the original work is properly cited.

\begin{abstract}
Thermal waters are natural resources of great value to geothermal sciences, the tourism industry, and health. In this work, geochemical classification of physicochemical results of 17 sources at the Puracé-La Mina (Cauca, Colombia) sector was implemented in order to strengthen and determine their potential applications and enhance the continental tourism in Colombia. The analyzed parameters were developed following the Standard Methods 22nd edition, at Universidad Nacional de Colombia-Manizales. According to the results obtained by means of a geochemical classification, it was found that most of the sources have a sulfated-acid nature which makes them heated vapor waters and volcanic waters. Likewise, it was observed that all the sources are immature waters and still do not reach chemical equilibrium. On the other hand, mineralogical and chemical characterization by means of XRD and XRF showed a high content of silica isomorphous minerals with a low concentration. In addition, the presence of $\mathrm{Fe}_{2} \mathrm{O}_{3}$ was observed, which is insoluble at $\mathrm{pH}>5$ and remains in the rock. Nevertheless, considering that mine sources possess $\mathrm{pH} \pm 2$ and temperatures of $40^{\circ} \mathrm{C}$, leaching is possible for iron justifying its presence in the water. Instead, elements like $\mathrm{Na}^{+}, \mathrm{K}^{+}, \mathrm{Mg}^{2+}$, and $\mathrm{Ca}^{2+}$ have high mobility at the conditions of mine sources (low $\mathrm{pH}$ ) as a consequence of hydrolysis processes, which produce variations in water composition.
\end{abstract}

\section{Introduction}

Geothermal processes are directly related to the composition of hot springs giving useful information about the components that affect these hot springs and allowing the evaluation of their applications [1], such as heating, medicinal applications, and bathing [2]. Hot springs can be located around the world in different countries and regions. These different locations make hot springs exhibit a great diversity of geophysical, geochemical, and biological properties depending on the region and the origin of the waters. In this way, rock and mineral chemistry is important in hot spring studies taking into account that information about water-rock interactions can be obtained [3].

These differences make hot springs an interesting area of research for specific biotechnological or ecological applications [4]. For this reason, several studies of hot springs placed in different countries have been reported in the literature as it is the case of Chabaane et al. [5] who developed a work that attempted to enhance and optimize the potential exploitation of the Hammam Sayala thermal spring in NW Tunisia. Using several electrical techniques, new information of the hydrothermal system in this region was obtained helping to create a therapeutic center for encouraging the regional thermal tourism development [5]. Kikawada et al. [6] performed a geothermometric study of hot spring waters in the Manza area near the Kusatsu-Shirane volcano. These studies might be meaningful for geochemical monitoring of active volcanoes through the changes in the calculated equilibrium temperatures of appropriate minerals for volcanic hot springs.

Apollaro et al. [7] carried out chemical and mineralogical characterization studies in Calabria, south Italy, which were aimed at evaluating the risks posed by pure amianthus (asbestos) tremolit rocks found in Unidad Gimigliano-Monte 
Reventino to human health. Results showed high contents of $\mathrm{Mn}, \mathrm{V}$, and $\mathrm{Cr}$ and a minimal presence of Fe. Traces of $\mathrm{Sr}, \mathrm{Cu}$, $\mathrm{As}, \mathrm{Pb}$, and $\mathrm{Ba}$ were also found in low concentrations. These element contents are in accordance with reports in literature, and some trace metals present in tremolit samples are highly harmful for the human health.

Marini et al. [8] carried out a route model of a reaction focused on simulating exchanges in the water-rock interaction between rain water sediments and local currents during the generation of $\mathrm{Ca}-\mathrm{HCO}_{3}^{-}$waters. This model was made by Marini and Ottonello [9] from data obtained in springs located in Bisagno valley (Italy) in 1996. From these results, the role that calcite plays can be highlighted, which absorbs trace elements of $\mathrm{Mn}, \mathrm{Zn}, \mathrm{Cd}$, and Co. This is due to the precipitation of calcite which is faster compared to the oxides and hydroxides of clays. Al adsorption of these elements from calcite can present a damper in the long term, which can disturb other processes.

Several reports on hot spring studies in Latin America have been found in Argentina, Brazil, and Mexico. Guido and Campbell [10] developed a study of Jurassic hot spring deposits of the Deseado Massif (Patagonia, Argentina), where they conducted a detailed geological mapping and sample analyses in five different sites that represented the variety of hot spring deposits in the region. With the purpose of observing the possibility of harvesting minerals from Rio Grande (Brazil) volcanic rocks, Ramos et al. [11] carried out studies in chemical and mineralogical characterization. They found that the availability of $\mathrm{P}, \mathrm{K}$, and macronutrients like $\mathrm{Zn}, \mathrm{Cu}, \mathrm{Fe}$, and $\mathrm{Mg}$, was evaluated by means of XRD, XRF, and ICP-MS. On the other hand, a low concentration of $\mathrm{Al}$ in aqueous media was evidenced, which is favorable for plants due to the toxicity of this element at high concentrations. Prieto-Barajas et al. [4] explored the diversity of bacterial culture communities residing in hot springs from Araró, México. They also analyzed the effect of seasonality and related changes in physicochemical parameters of spring waters. Physicochemical parameters, measured every season, showed slight variations except for the temperature and arsenic concentration. Then, taking into account that each hot spring has its own characteristics, there is a great interest in performing studies of hot springs in Puracé-La Mina (Cauca, Colombia) to identify their peculiarities.

With this objective in mind, Megyesi [12] reported studies regarding sulfur deposits in the Puracé sector in order to corroborate that mineralization occurs in the porous rocks of andesite and dacite tuffs through fractures impregnated and filled with cold sulfur. On the other hand, in the INGEOMINAS (for its acronym in Spanish: Instituto Colombiano de Geología y Minería) report, Garzón [13] reported studies of geochemical analysis in the Puracé sector, including sources in several sites like Piscina Tabio, La Mina, and Pilimbalá, among others and registered the type of water according to the cations and anions. This study was performed around 20 years ago and, since then, the studied sources could have been affected by several causes such as changes in the weather and the influence of the inhabitants of this region, among others. Consequently, it is necessary to updated these studies and add other sources.
It is also of great importance to classify hot springs. Thermal fluids, for instance, can be classified as primary and secondary types. The primary thermal fluids are deep deposits originating from magmatic waters that can undergo changes during their rise to the surface. The secondary thermal fluids are shallow fluids that generally come from the primary fluids. Such fluids can be of several types, including chlorinated, sulfated acid or carbonated fluids [14-18]. Mineral waters emerge to the surface in a natural way [19]. During the rise of the water to the surface, it undergoes compositional changes [17] due to cationic exchange processes, hydrolysis [20], boiling, cooling, and leaching with rocks $[16,21]$. The elemental and chemical compositions have been studied by analyzing the mineralogy, finding the water alteration, and observing rocks such as pyrite, elemental sulfur, zeolites, and clays. Chlorite, among others, produces changes in the fluids [16]. Although a classification was carried out to some of these waters and sources, it is necessary to develop a broad study of several characteristics that allows classifying a great quantity of sources in this area in order to find more suitable applications.

It is well known that territories like Puracé-La Mina can have huge potential applications in tourism and sulfur and other mineral harvesting. As a consequence, it is important to consider all the variables in order to evaluate the possibilities of industrial applications in this sector. One of these variables is the quality of water and the presence of minerals in rocks from a physicochemical analysis and mineralogical characterization. The study was divided into three parts, according to the location in the region of Cauca. In this work, geochemical classifications of physicochemical results are carried out in order to strengthen the mineralogical characterization of thermal water in 17 sources of Puracé-La Mina (Cauca, Colombia, South America) to acquire information that contributes to enhancing the continental tourism in Colombia.

\section{General Geological Setting}

Colombia is located in South America, between the Pacific and Atlantic oceans. Colombia has a wide diversity of geothermal systems (approximately 300) located in the zones of Paipa, Azufral, Ruiz, Chiles, Cumbal, Galeras, Sotará, Doña Juana, Huila, and Puracé UPME (for its acronym in Spanish: Unidad de Planeación Minero Energética) [22, 23]. Puracé is located in the Andean Region of Colombia, southeast of the city of Popayán, Department of Cauca, in the Cordillera Central mountain range (Figure 1). According to Simkin and Institution, the study area is close to the Puracé volcano, which has presented volcanic activity in the last century [24]. According to the reports by Sturchio et al. [25], a detailed geological map of the area has not been made. However, Oppenheim [26] mentions that this volcanic area is a dacitic shield and rises on a metamorphic basement from 2600 to 3800 meters above sea level, covered by a pyroclastic lava andesitic cone [27].

The 17 sources included in this study are shown in Figure 2. In this figure, the studied sites are described according to the reports developed by INGEOMINAS as 


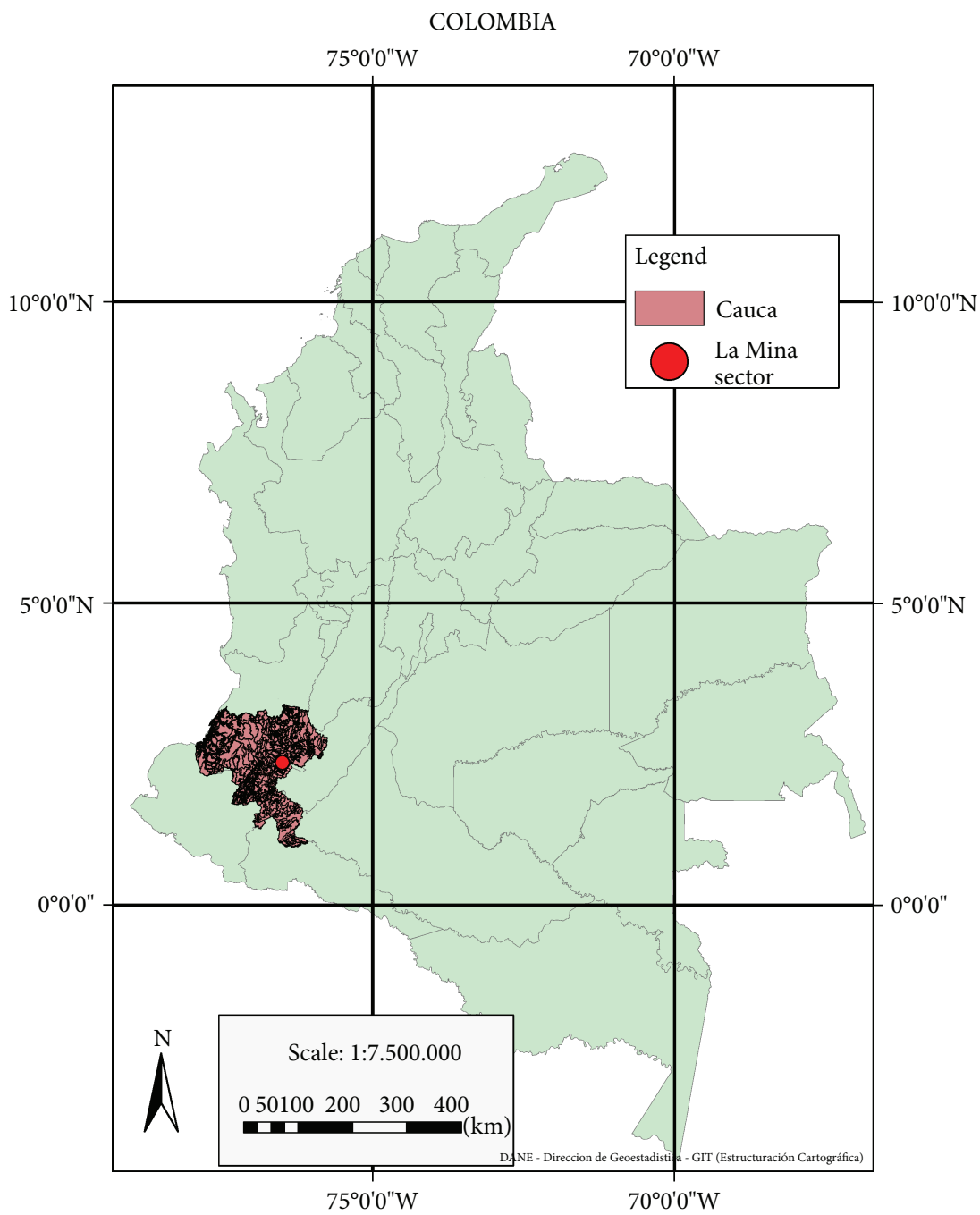

Figure 1: Colombian map and location of La Mina sector. Map of the Agustin Codazzi Geographic Institute [54].

follows: COMI (upwellings in La Mina) (Figure 3(a)), COPU (Pululó sector upwellings), COCI (natural waterfall of Ichiago) (Figure 3(b)), COPT (natural upwelling of Puente Tierra (Pilimbala), COTA (upwelling of Piscina Tabio), COPV (water birth of Plan del Vinagre), COSA (waterfall of San Antonio) (Figure 3(c)), and COGU (upwellings of Guarquelló) [13]. Their respective classifications, georeferences, and codifications are listed in Table 1.

\section{Sampling and Analysis Methodology}

3.1. Sampling. Twelve representative samples of surface manifestations were collected on May 2017 from the geothermal systems of the Puracé-La Mina sector (Table 1) for the analysis of the physicochemical properties of interest. The type of sampling performed was simple or timely. The sampling was carried out in 10-liter containers, with 1-liter graduations. The vessel was purged two or three times, and it was then placed in the flow, measuring the time with a timer. In this way, the parameter $Q=V / t$ was obtained. The flow, $Q$ is given in $L / s$, where $V$ and $t$ represent the volume and time, respectively. During the sampling, $\mathrm{HNO}_{3}$ was added until $\mathrm{pH}<2$ for hardness and metal analyses; $\mathrm{pH}$, temperature, and conductivity parameters were measured for all samples. Titanium and ORP analysis was not carried out in this study.

The seven representative solid samples of the sector were taken on November 2017 in the sources P1-A, P1-B, P2-A, P2-B, P3-A, P3-B, and P10-A for the XRD and XRF analyses.

\subsection{Analysis Methodology}

3.2.1. Physicochemical Characterization of the Sources. Physicochemical characterization of the sources was carried out in the Water Laboratory at Universidad Nacional de Colombia-Manizales, based on Standard Methods 22nd edition [28], and the laboratory is accredited by IDEAM (for its acronym in Spanish: Instituto de Hidrología, Meteorología y Estudios Ambientales) through the ISO standard 17025. Some of the methods of analysis are described as follows: The total hardness was determined by means of the $2340-C$ EDTA method, with an aliquot of $15 \mathrm{~mL}$ at a concentration of $0.01 \mathrm{M}$ of EDTA. Then, $2 \mathrm{~mL}$ of ammoniacal buffer solution and 2 drops of eriochrome black indicator were added 

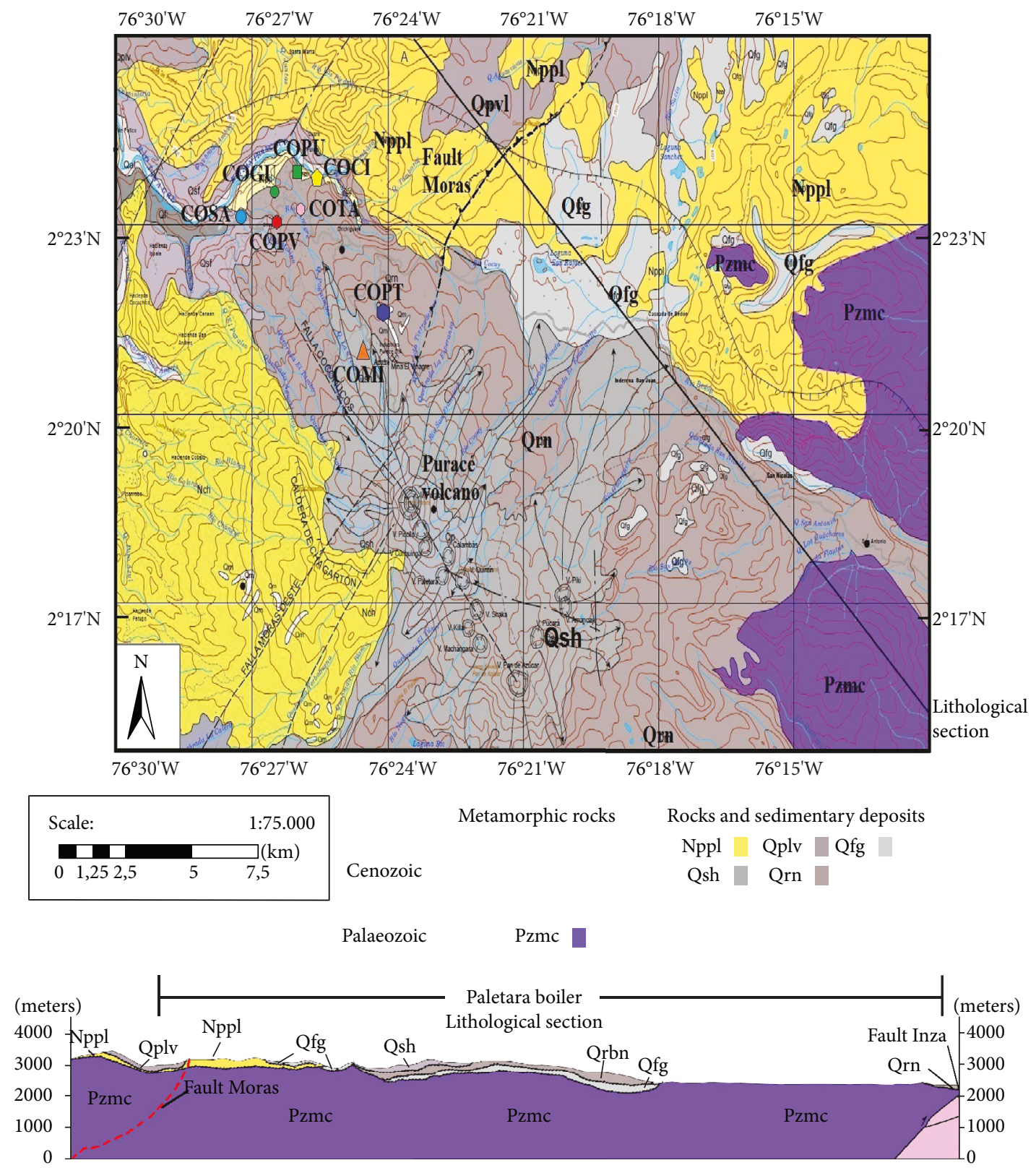

Figure 2: Location of the monitoring sites of the Puracé-La Mina sector and lithological section. Map of the Servicio Geológico Colombiano [55]. Nppl (lavas of andesitic compositions), Qplv (ash flow reservoirs), Qfg (fluvioglacial deposits), Qsh (andesitic lava), Qrn (andesitic lava) (Batolito Ibagué), and Pzmc (green and black shales).

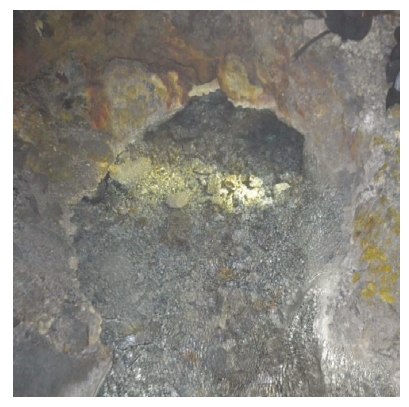

(a)

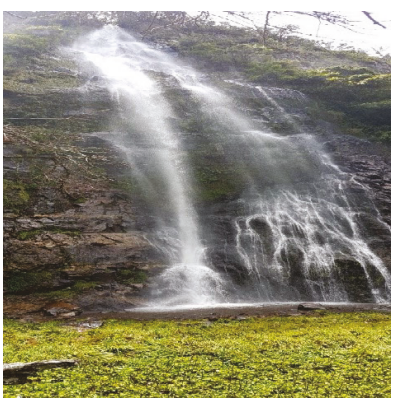

(b)

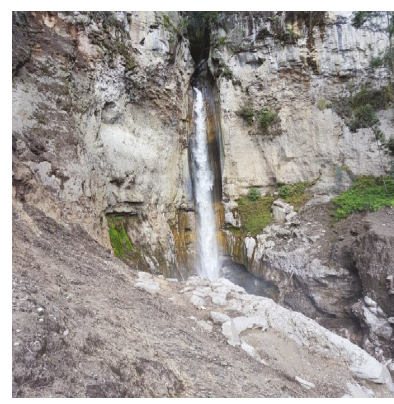

(c)

FIgURE 3: (a) Upwelling of the mine placed at approximately $1700 \mathrm{~m}$ inside the sulfur mine, (b) waterfall of Ichiago, and (c) waterfall of San Antonio. 
TABle 1: Points of the Puracé-La Mina sector.

\begin{tabular}{|c|c|c|c|c|}
\hline Code & Cod. & Source & $\mathrm{N}$ & $\mathrm{W}$ \\
\hline \multirow{5}{*}{ COMI } & $\mathrm{P} 1$ & The mine upwelling & \multirow{2}{*}{$2^{\circ} 21^{\prime} 2.2^{\prime \prime} *$} & \multirow{2}{*}{$76^{\circ} 24^{\prime} 32.7^{\prime \prime}$ * } \\
\hline & $\mathrm{P} 2$ & Water jet of rock 2 mine & & \\
\hline & P3 & Outside of carpentry & $2^{\circ} 21^{\prime} 06.8^{\prime \prime}$ & $076^{\circ} 24^{\prime} 36.1^{\prime \prime}$ \\
\hline & $\mathrm{P} 4$ & Water jet of soda mine & \multirow{2}{*}{$2^{\circ} 21^{\prime} 2.2^{\prime \prime} *$} & \multirow{2}{*}{$76^{\circ} 24^{\prime} 32.7^{\prime \prime} *$} \\
\hline & P5 & Water jet of rock 1 mine & & \\
\hline \multirow{2}{*}{ COPU } & P6 & Upwelling of soda water & $2^{\circ} 21^{\prime} 2.2^{\prime \prime}$ & $76^{\circ} 24^{\prime} 32.7^{\prime \prime}$ \\
\hline & P7 & Waterfall of Pululó village & $2^{\circ} 23^{\prime} 42.5^{\prime \prime}$ & $076^{\circ} 25^{\prime} 54.0^{\prime \prime}$ \\
\hline COCI & P8 & Waterfall of Ichiago & $2^{\circ} 23^{\prime} 38.5^{\prime \prime}$ & $076^{\circ} 25^{\prime} 23.7^{\prime \prime}$ \\
\hline \multirow{2}{*}{ COPT } & P9 & Intake tank of natural water of Puente Tierra & $2^{\circ} 21^{\prime} 36.9^{\prime \prime}$ & $076^{\circ} 24^{\prime} 4.9^{\prime \prime}$ \\
\hline & $\mathrm{P} 10$ & Pool of Puente Tierra & $2^{\circ} 21^{\prime} 46.6^{\prime \prime}$ & $076^{\circ} 24^{\prime} 12.0^{\prime \prime}$ \\
\hline \multirow{2}{*}{ COTA } & P11 & Tabio, lateral upwelling of pool & $2^{\circ} 23^{\prime} 7.1^{\prime \prime}$ & $076^{\circ} 25^{\prime} 49.5^{\prime \prime}$ \\
\hline & $\mathrm{P} 12$ & Tabío, behind the pool & $2^{\circ} 23^{\prime} 6.8^{\prime \prime}$ & $076^{\circ} 25^{\prime} 49.7^{\prime \prime}$ \\
\hline COPV & P13 & Before the bridge of Rio Vinagre & $2^{\circ} 22^{\prime} 55.4^{\prime \prime}$ & $76^{\circ} 26^{\prime} 17.5^{\prime \prime}$ \\
\hline \multirow[t]{2}{*}{ COSA } & $\mathrm{P} 14$ & Waterfall of San Antonio & $2^{\circ} 23^{\prime} 0.6^{\prime \prime}$ & $76^{\circ} 27^{\prime} 2^{\prime \prime}$ \\
\hline & P15 & Upwelling of rock 1 in Guarqueyó & $2^{\circ} 23^{\prime} 26.3^{\prime \prime}$ & $76^{\circ} 26^{\prime} 21.0^{\prime \prime}$ \\
\hline \multirow[t]{2}{*}{ COGU } & P16 & Upwelling of rock 2 in Guarqueyó & $2^{\circ} 23^{\prime} 26.8^{\prime \prime}$ & $76^{\circ} 26^{\prime} 24.6^{\prime \prime}$ \\
\hline & $\mathrm{P} 17$ & Upwelling of rock 3 in Guarqueyó & $2^{\circ} 23^{\prime} 26.8^{\prime \prime}$ & $76^{\circ} 26^{\prime} 25.0^{\prime \prime}$ \\
\hline
\end{tabular}

*It is located inside the sulfur extraction mine about $1800 \mathrm{~m}$ from the entrance. In the interior, no coordinates were taken; then, the coordinates of the entrance are recorded at a height of 3607 MAMSL (meters above mean sea level). Code, codification (Cod.), source, coordinates refer to 17 sources.

and, finally, it was labeled. The nitrates were determined by means of the $4500-\mathrm{NO}_{3}-\mathrm{B}$ method. The sample was filtered and acidified with $1 \mathrm{~mL}$ of $\mathrm{HCl}$, at a concentration of $1.0 \mathrm{M}$. Afterwards, a calibration curve was obtained plotting the absorbance as a function of the concentration with standards prepared from a certificated $\mathrm{NO}_{3}$ nitrate standard in a range between 0 and $7 \mathrm{mg}-\mathrm{N} / \mathrm{L}$. Finally, the measurement was made using a UV spectrophotometer (Perkin Elmer UV-Vis Spectrometer Lambda 20) with a lambda $=220 \mathrm{~nm}$. The $\left(\mathrm{SO}_{4}\right)^{2-}$ ions were determined by means of the $4500\left(\mathrm{SO}_{4}\right)^{2-}-E$ method with $20 \mathrm{~mL}$ of buffer solution to a sample of $100 \mathrm{~mL}$. Later, the sample was agitated, and afterwards, $\mathrm{BaCl}_{2}$ was added and the measurement was made using a turbidimeter. For the $\mathrm{Cl}^{-}$ions, the $4500-\mathrm{Cl}-\mathrm{B}$ method was used, where a sample of $100 \mathrm{~mL}$ was taken. For those which were too colored, $3 \mathrm{~mL}$ of $\mathrm{Al}(\mathrm{OH})_{3}$ was added. Then, it was filtered, the $\mathrm{pH}$ was fixed between 7 and 10, and finally, it was labeled with $\mathrm{AgNO}_{3}$, using $\mathrm{K}_{2} \mathrm{CrO}_{4}$ as an indicator. Atomic absorption by flame was employed for metal detection using the iCE 3000 (Thermo Fisher Scientific) equipment; the limits of detection are shown in Table 2. Turbidity was determined by means of the 2130-B. A Metrohm Swiss-made device was used for the $\mathrm{pH}-\mathrm{L}$ measurements, $\mathrm{pH}=4$. A Merck buffer solution (citric acid/sodium hydroxide/hydrogen chloride) and Merck $\mathrm{pH}=7$ buffer solution (disodium hydrogen phosphate/potassium dihydrogen phosphate) were used. Metrohm Swiss-quality titration equipment was used for the multiprobe analysis, and the charge imbalance is carried out using PHREEQC software.
Table 2: Atomic absorption by flame.

\begin{tabular}{lc}
\hline Metal & Detection limit $(\mathrm{ppm})$ \\
\hline $\mathrm{Fe}$ & 0.0043 \\
$\mathrm{Al}$ & 0.0280 \\
$\mathrm{Zn}$ & 0.0037 \\
$\mathrm{Na}$ & 0.0037 \\
$\mathrm{~K}$ & 0.0009 \\
$\mathrm{Ca}$ & 0.0037 \\
$\mathrm{Mg}$ & 0.0022 \\
$\mathrm{Mn}$ & 0.0016 \\
\hline
\end{tabular}

3.2.2. Mineralogical Characterization. The mineralogical characterization was carried out in the GMAS ${ }^{+}$Laboratory, Bogotá, Colombia. For the XRD and XRF analyses, the samples were pulverized and sieved with $63 \mu \mathrm{m}$ nets at an approximate weight of $2 \mathrm{~g}$.

The mineralogical composition and structural parameters of the rocks were evaluated by XRD with an X-ray diffractometer (Bruker D8 Advance-series I) that was operated at $20 \mathrm{kV}$ and $30 \mathrm{~mA}$, with an X-ray source emitting CoK $(1.7890 \mathrm{~A})$ radiation. The measuring range was from 5 to 70 with a scan speed of $0.3 \mathrm{~s} / \mathrm{step}$ and a step size of 0.015 ; a nickel filter was used. The analysis was carried out using the EVA [29] and TOPAS software [30].

For the XRF measurements, the samples were dried at $105^{\circ} \mathrm{C}$ for 12 hours. Then, spectrometry wax (Merck) was 
TABle 3: Major element concentrations of the geothermal waters from the Puracé-La Mina sector, Cauca, Colombia. Units are in ppm, total hardness $\left(\mathrm{CaCo}_{3}\right)$, less than detection limit $(<\mathrm{DL})$, not detectable $(\mathrm{ND})$, and charge imbalance $(\mathrm{CI})$.

\begin{tabular}{lcccccccccccccc}
\hline Sample & $\mathrm{SO}_{4}$ & $\mathrm{Cl}^{-}$ & $\mathrm{Na}$ & $\mathrm{K}$ & $\mathrm{Ca}$ & $\mathrm{Mg}$ & $\mathrm{Fe}$ & $\mathrm{Mn}$ & $\mathrm{Al}$ & $\mathrm{HCO}_{3}^{-}$ & $\mathrm{CO}_{3}^{2-}$ & $\mathrm{CaCo}_{3}$ & $\mathrm{~F}^{-}$ & $\mathrm{CI}^{2}$ \\
\hline P1 & 3242 & 949 & 405 & 72.5 & 367 & 286 & 64.6 & 8.3 & 79.4 & 0.0 & 0.0 & 1653 & 0.1 & $5: 8$ \\
P2 & 3356 & 1056 & 348 & 132 & 178 & 240 & 76.4 & 11.0 & 113 & 0.0 & 0.0 & 1890 & 0.1 & $16: 3$ \\
P3 & 3162 & 903 & 260 & 79.6 & 283 & 270 & 80.4 & 4.8 & 119 & 0.0 & 0.0 & 1593 & 0.1 & $9: 5$ \\
P4 & 3633 & 1129 & 375 & 103 & 543 & 377 & 75.5 & 12.4 & 188 & 0.0 & 0.0 & 1930 & 0.1 & $5: 8$ \\
P5 & 3809 & 1153 & 268 & 87.8 & 457 & 316 & 75.9 & 13.2 & 171 & 0.0 & 0.0 & 1930 & 0.1 & $8: 3$ \\
P6 & 950 & 218 & 69.4 & 16.4 & 56.3 & 82.5 & 5.1 & 3.0 & 35.7 & 0.0 & 0.0 & 485 & 0.1 & $4: 3$ \\
P7 & 969 & 362 & 81.1 & 21.5 & 62.2 & 97.6 & 12.2 & 3.6 & 38.8 & 0.0 & 0.0 & 544 & 0.1 & $18: 2$ \\
P8 & 36.4 & 1.3 & 2.3 & 1.8 & 3.6 & 1.9 & $<\mathrm{IDL}$ & $<\mathrm{IDL}$ & $\mathrm{IDL}$ & 15.2 & 0.0 & 19.8 & 0.0 & $39: 8$ \\
P9 & 7.8 & 1.3 & 1.3 & 1.1 & 0.9 & 0.6 & 0.6 & $<\mathrm{IDL}$ & $\mathrm{IDL}$ & 14.0 & 0.0 & 10.9 & 0.0 & $70: 9$ \\
P10 & 156 & 36.4 & 18.9 & 4.8 & 34.5 & 13.3 & $<\mathrm{IDL}$ & 0.4 & 3.1 & 0.0 & 0.0 & 128 & 0.1 & $0: 3$ \\
P11 & 964 & 355 & 110 & 25.7 & 74.0 & 85.2 & 22.0 & 3.4 & 37.4 & 0.0 & 0.0 & 702 & 0.1 & $13: 6$ \\
P12 & 131 & 56.5 & 6.0 & 5.7 & 38.6 & 15.4 & 3.2 & 0.7 & 5.6 & 0.0 & 0.0 & 150 & 0.1 & $6: 3$ \\
P13 & 117 & 76.5 & 23.3 & 8.1 & 14.0 & 26.1 & 1.8 & 1.3 & 15.7 & 0.0 & 0.0 & 178 & 0.1 & $16: 9$ \\
P14 & 2058 & 462 & 128 & 36.1 & 104 & 90.5 & 92.1 & 4.6 & 51.6 & 0.0 & 0.0 & 830 & 0.1 & $29: 2$ \\
P15 & 934 & 274 & 76.2 & 17.4 & 61.3 & 67.9 & 7.3 & 3.3 & 41.2 & 0.0 & 0.0 & 530 & 0.1 & $20: 4$ \\
P16 & 907 & 266 & 70.8 & 18.8 & 62.3 & 81.2 & 6.7 & 3.2 & 40.0 & 0.0 & 0.0 & 470 & 0.1 & $16: 4$ \\
P17 & 911 & 256 & 67.0 & 18.6 & 96.4 & 87.3 & 8.2 & 3.2 & 27.8 & 0.0 & 0.0 & 475 & 0.1 & $13: 8$ \\
\hline
\end{tabular}

added in 10:1 ratio and the samples were homogenized by means of a hydraulic press at $120 \mathrm{kN}$ for one minute until pills of $337 \mathrm{~mm}$ diameter were obtained. The XRF semiqualitative analysis was done with the SemiQ 5 software, scanning 11 times with the purpose of detecting all the elements present in the sample excluding $\mathrm{H}, \mathrm{C}, \mathrm{Li}, \mathrm{Be}, \mathrm{B}, \mathrm{N}$, and $\mathrm{O}$, and the transuranic elements.

\section{Results}

4.1. Physicochemical Analyses. The physicochemical composition of the 17 sources of the Puracé-La Mina sector are shown in Tables 3 and 4 . The sources present mostly acidic $\mathrm{pH}$, but ions of sulfates (up to $3809 \mathrm{ppm}$ ) and chlorides (up to $1153 \mathrm{ppm}$ ) and a total hardness of up to $1930 \mathrm{ppm}$ are the most predominant. The concentrations of some metals such as $\mathrm{Zn}$ and $\mathrm{Cr}$ are low or very low and were below the limit of quantification. The sources exhibited maximum and minimum temperatures of $48^{\circ} \mathrm{C}$ and $9.7^{\circ} \mathrm{C}$, respectively.

Table 4 shows that $\mathrm{pH}$ values measured in the laboratory were lower than those measured on the site, finding decrements of $2.1 \mathrm{pH}$ units for P8 and P9 sources and $\pm 0.3 \mathrm{pH}$ units for the other sources. This change is attributed to the temperature variations due to transport from the sampling site to the laboratory. As a consequence of this decrease of temperature, a dissociation of $\left(\mathrm{HSO}_{4}\right)^{2-}$ ions [31] and secondary ion precipitation were produced [32].

The chemical classification of the 17 sources of the Puracé-La Mina sector, based on the majority of the ions, was represented by Piper (Figure 4) and Stiff diagrams (Figure 5).

Table 5 shows that most of the waters are partially equilibrated with 13 sources $(76 \%)$, while 3 sources $(18 \%)$ of waters were magnesium type, and only one source (6\%) was calcium type. Likewise, in the classification of the anions (Table 5), it was observed that 16 sources (94\% of waters) were of sulfated type and one source $(6 \%)$ of partially bicarbonated type, corresponding to the natural water source.

The classification of the 17 sources analyzed in this work was developed according to water type with the following percentages: 4 sources (24\%) of sodium chloride and potassium, and sulfate magnesium; 6 sources (35\%) of sodium chloride and potassium sulfated magnesium; 2 sources (12\%) of sodium chloride and magnesium; 2 sources (12\%) of chloride and sulfated calcium, and one source (12\%) of mildly sulfated bicarbonate, chloride-type calcium, and sulfated magnesium, respectively.

Taking into account the previous classification, it was observed that the majority of the waters in the Puracé-La Mina sector are of sulfated nature. The sulfated water has an acidic nature with a $\mathrm{pH}$ lower than 4 . In the studied cases, it was observed that most sources have a $\mathrm{pH}$ between 2.15 and 3.93, discarding the sources of COCI and COPT. These waters would correspond to acidic waters heated with vapor, which occurs after the boiling of the thermal waters.

$\mathrm{Cl}^{-} /\left(\mathrm{SO}_{4}\right)^{2-}$ correlation showed $R^{2}=0.98$. This ratio of salinity of the COMI source is relatively high in comparison to other sources. Sources with lower salinity are Guarquelló sources (P15, P16, and P17) that possess similar features and moderate salinity. Finally, P8 and P9 are sources with low salinity [33] as is shown in Figure 6(a). Likewise, ratios of $\mathrm{Cl}^{-} /\left(\mathrm{SO}_{4}\right)^{2-}$ under 0.65 indicate that La Mina sector waters are not developing during a long period of time and at a depth enough to react with rock [34]. On the other hand, considering the total ionic salinity $[35,36]$ (Figure 6(c)), the following observations were made: 
TABle 4: Major element concentrations of the geothermal waters from the Puracé-La Mina sector, Cauca, Colombia. Units are in ppm; laboratory (pH-L), on site ( $\mathrm{pH}-\mathrm{S}$ ), suspended solid totals (SST), conductivity (C) (in $\mu \mathrm{S} / \mathrm{cm}$ ), flow (F) (in L/s), dissolved oxygen (DO), not detectable (ND), less than detection limit $(<\mathrm{IDL})$.

\begin{tabular}{lcccccccccccc}
\hline Sample & $t\left({ }^{\circ} \mathrm{C}\right)$ & $\mathrm{pH}-\mathrm{S}$ & $\mathrm{pH}-\mathrm{L}$ & $\mathrm{F}$ & $\mathrm{C}$ & $\mathrm{SST}$ & $\mathrm{Cr}$ & $\mathrm{NO}_{3}$ & $\mathrm{NO}_{2}$ & $\mathrm{DO}$ & $\mathrm{Si}$ & $\mathrm{Zn}$ \\
\hline P1 & 47.0 & 2.21 & 1.99 & 22.4 & 9790 & 0.5 & $<\mathrm{IDL}$ & 0.3 & $\mathrm{ND}$ & 0.0 & 45.4 & 1.0 \\
P2 & 48.0 & 2.14 & 1.89 & 22.3 & 11,230 & 5.0 & $<\mathrm{IDL}$ & 0.3 & $\mathrm{ND}$ & 0.0 & 48.9 & 1.2 \\
P3 & 40.6 & 2.17 & 1.93 & - & 9780 & 4.0 & $<\mathrm{IDL}$ & 0.3 & 0.5 & 0.0 & 60.6 & 1.0 \\
P4 & 40.0 & 2.27 & 1.92 & 0.15 & 11,650 & 22.0 & $<\mathrm{IDL}$ & 0.3 & $\mathrm{ND}$ & 0.0 & 53.7 & 1.2 \\
P5 & 36.0 & 2.15 & 1.86 & 10.7 & 11,710 & 19.0 & $<\mathrm{IDL}$ & 0.5 & 0.1 & 0.0 & 50.4 & 1.2 \\
P6 & 24.4 & 2.88 & 2.52 & 1.8 & 2660 & 5.5 & $<\mathrm{IDL}$ & 0.8 & 0.2 & 0.0 & 34.5 & 0.3 \\
P7 & 21.3 & 2.72 & 2.36 & 13.7 & 3160 & 4.5 & $<\mathrm{IDL}$ & 1.8 & 0.1 & 0.0 & 38.7 & 0.4 \\
P8 & 15.3 & 8.08 & 5.98 & 98.3 & 50.3 & 1.5 & $<\mathrm{IDL}$ & 0.2 & 0.5 & 7.5 & 7.7 & $<\mathrm{IDL}$ \\
P9 & 9.7 & 7.81 & 5.68 & 11.9 & 26.2 & 3.0 & $<\mathrm{IDL}$ & 0.1 & 1.2 & 5.5 & $\mathrm{IDL}$ & $<\mathrm{IDL}$ \\
P10 & 16.7 & 3.93 & 4.16 & 3.4 & 391 & 4.0 & $<\mathrm{IDL}$ & 0.1 & $\mathrm{ND}$ & 1.2 & 21.5 & $<\mathrm{IDL}$ \\
P11 & 26.6 & 2.72 & 2.35 & 12.1 & 3900 & 2.0 & $<\mathrm{IDL}$ & 2.2 & 2.1 & 3.0 & 41.4 & $<\mathrm{IDL}$ \\
P12 & 14.2 & 3.39 & 3.15 & 40.3 & 604 & 6.5 & $<\mathrm{IDL}$ & 0.3 & $\mathrm{ND}$ & 6.7 & 10.8 & 0.0 \\
P13 & 16.7 & 3.70 & 3.40 & 3.3 & 755 & 2.5 & $<\mathrm{IDL}$ & 0.6 & $\mathrm{ND}$ & 0.0 & 27.5 & 0.1 \\
P14 & 16.9 & 2.37 & 2.05 & 69.3 & 6490 & 8.5 & $<\mathrm{IDL}$ & 12.0 & 2.9 & 4.6 & 35.4 & 0.5 \\
P15 & 21.7 & 2.77 & 2.54 & 0.1 & 3010 & 6.5 & $<\mathrm{IDL}$ & 1.0 & 0.3 & 0.0 & 38.0 & 0.3 \\
P16 & 22.3 & 2.81 & 2.59 & 0.9 & 2710 & 1.5 & $<\mathrm{IDL}$ & 0.9 & 1.6 & 0.0 & 38.1 & 0.3 \\
P17 & 22.0 & 2.81 & 2.57 & 0.7 & 2830 & 2.0 & $<\mathrm{IDL}$ & 0.9 & $\mathrm{ND}$ & 0.0 & 39.3 & 0.3 \\
\hline
\end{tabular}

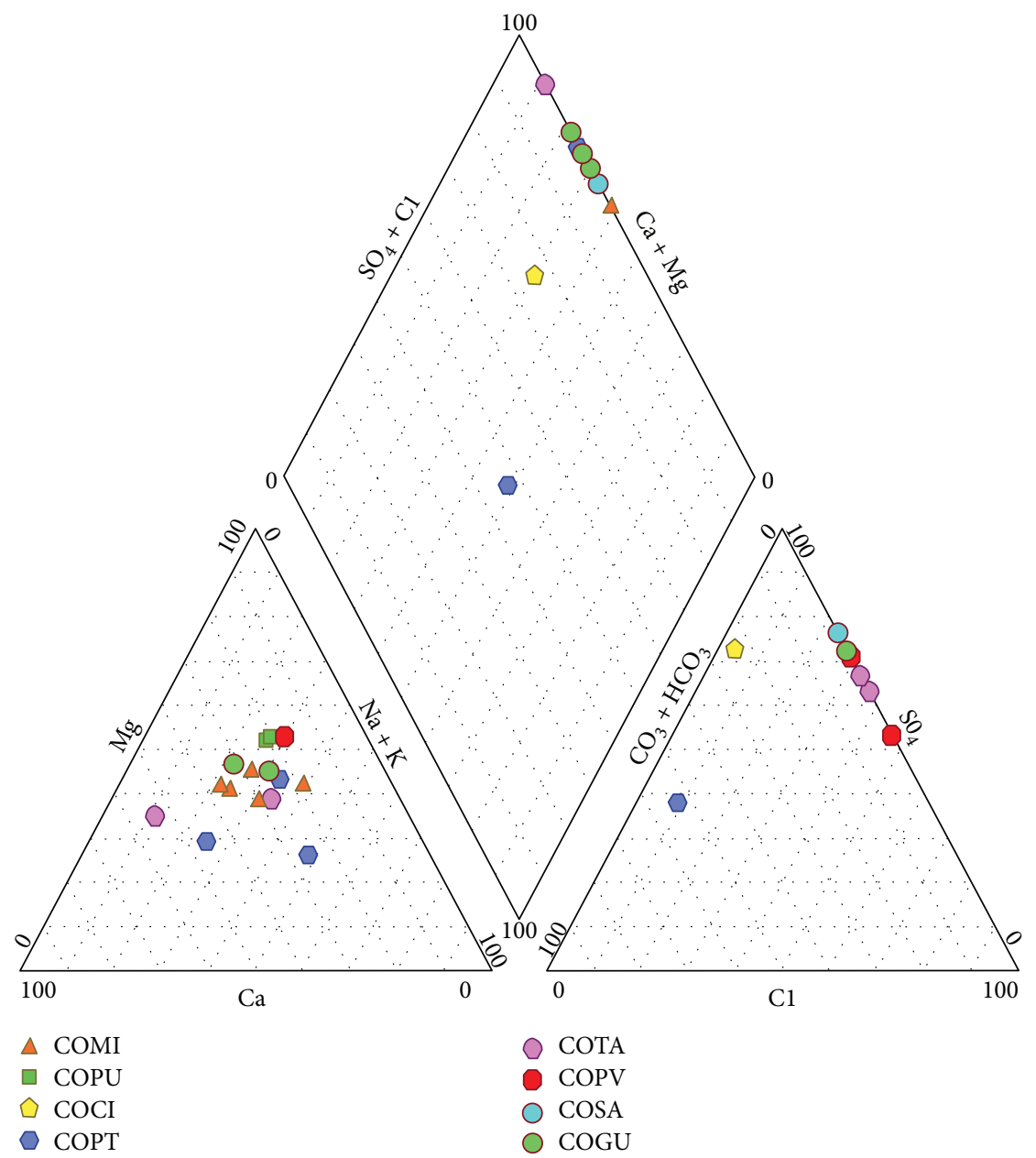

Figure 4: Piper diagram showing the hydrochemical compositions of some hot springs in the Puracé-La Mina sector. 


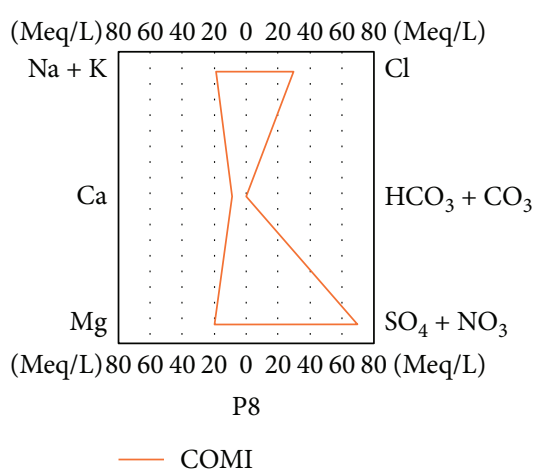

(a)

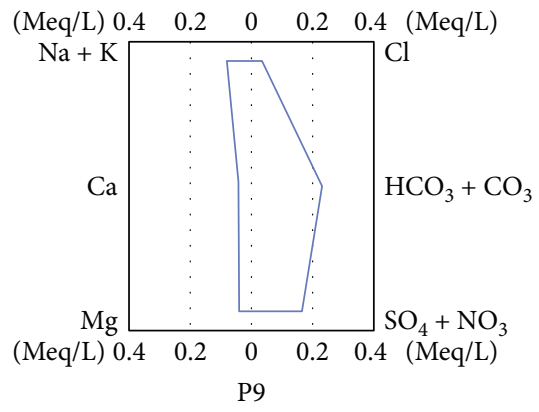

- COPT

(c)

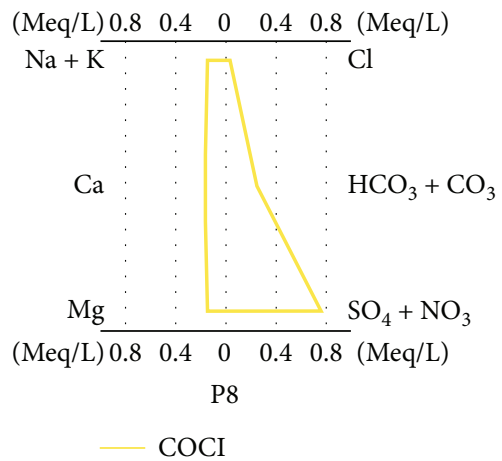

(b)

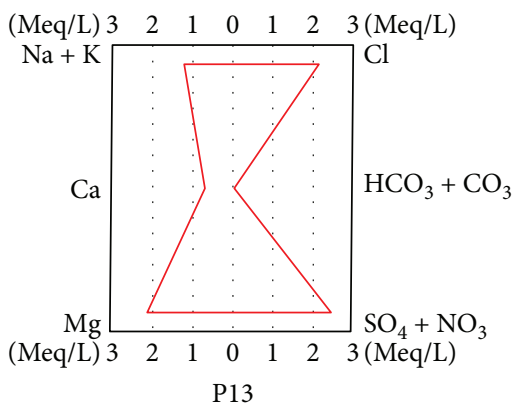

(d)

Figure 5: Representative Stiff diagrams of the sources of the Puracé-La Mina sector.

(1) For COMI sources, a TIS between 200 and $250 \mathrm{meq} / \mathrm{L}$ is observed, which supposes that chemical features were acquired to depth levels by means of water-rock interaction with smooth rocks and dolomite, although $\mathrm{Na} / \mathrm{K}$ ratios do not exceed 10 equivalent units

(2) For the case of other sources, their majority present a TIS between 0 and $100 \mathrm{meq} / \mathrm{L}$, and $\mathrm{Na} / \mathrm{K}$ ratios are below the COMI ones and do not exceed 7 equivalent units. This low salinity indicates that waters from these sources come from low-depth wells and can be a product of a mixture of cold and warm waters

The high correlation value $R^{2}=0.83$ between $\mathrm{Cl}^{-} / \mathrm{Ca}^{2+}$ ions confirms the strong presence of chloride-calcium waters. Similarly, high correlations were obtained for $\mathrm{Cl}^{-} / \mathrm{Na}$, $\mathrm{Cl}^{-} / \mathrm{K}^{+}$, and $\mathrm{Cl}^{-} / \mathrm{Mg}^{2+}$ with $R^{2}=0.919, R^{2}=0.917$, and $R^{2}=0.954$, respectively, as shown in Figure $6(\mathrm{~b})$. These relationships indicate that soluble salts prevail in most of the sources of the area and that $\mathrm{Ca}^{2+}$ and $\mathrm{Mg}^{2+}$ are causing hardness in the samples $[34,37]$.

For the classification of hardness, the following parameters were established by the World Health Organization (WHO): soft type, 0-60; moderately hard, 61-120; hard, 121-180; and very hard, >180 ppm of $\mathrm{CaCO}_{3}$, respectively. Based on the results of Table 3, sources in the Puracé-La Mina sector contain two soft-type sources, three hard-type sources and, twelve very-hard-type sources. From this classification, COMI sources stand out, which have values between 1653.3 and $1930 \mathrm{ppm}$ of $\mathrm{CaCO}_{3}$. According to the literature, the mobile elements such as $\mathrm{Na}, \mathrm{K}, \mathrm{Mg}$, and $\mathrm{Ca}$ are the product of the lixiviation of clay minerals such as rhyolites [16, 38], which may be responsible for the high presence of these ions, in the sources in the Puracé-La Mina sector.

4.2. $\mathrm{Cl}^{-},\left(\mathrm{SO}_{4}\right)^{2-}$, and $\left(\mathrm{HCO}_{3}\right)^{-}$Giggenbach Diagram. In Figure 7 , all the samples were classified according to the ternary diagram $\mathrm{Cl}^{-}-\left(\mathrm{SO}_{4}\right)^{2-}-\left(\mathrm{HCO}_{3}\right)^{-}$described by Giggenbach in 1988 [39]. In this type of sources, $\mathrm{HCl}$ is assumed to be derived from $\mathrm{HCl}$ of magmatic origin, $\left(\mathrm{SO}_{4}\right)^{2-}$ from the oxidation of magmatic $\mathrm{SO}_{2}$, and $\mathrm{HCO}_{3}$ from $\mathrm{CO}_{2}$. This anions are generally associated with the acid immature waters of fluids originally magmatic [32, 40].

Most of the sources are sulfated-acid type as it is observed in Figure 4 and Table 5. In Figure 7, the sources are grouped in the volcanic origin sections, which are typical of volcanic geothermal systems associated to volcanos. These sources have low $\mathrm{pH}$ value, caused by the $\mathrm{Cl}^{-}$and $\left(\mathrm{SO}_{4}\right)^{2-}$ ions which, in turn, form a $\mathrm{HSO}_{4}^{-} /(\mathrm{SOP})^{2-}$ buffer. During the water-rock interaction process, this system produces higher rock dissolution, generating higher conductivity $[14,41]$. In the case of the COMI sources (Figure 5(a)), higher metal concentrations were observed, such as $\mathrm{Fe}$ and $\mathrm{Si}$, which in turn produce oxides such as $\mathrm{SiO}_{2}$ (from minerals like cristobalite, quartz, tridmite, among others) and $\mathrm{Fe}_{2} \mathrm{O}_{3}$ (pyrite). Those minerals have covalent bonds which are very difficult to break; 
Table 5: Chemical classification of waters of the Puracé-La Mina sector, according to cations, anions, and water type.

\begin{tabular}{|c|c|c|c|}
\hline Sample & Cations & Anions & Water type \\
\hline P1 & Partially equilibrated & Sulfated type & $\begin{array}{l}\text { Chlorinated sodium and calcium } \\
\text { Sulfated sodium and potassium }\end{array}$ \\
\hline $\mathrm{P} 2$ & Partially equilibrated & Sulfated type & $\begin{array}{l}\text { Chlorinated sodium and calcium } \\
\text { Sulfated sodium and potassium }\end{array}$ \\
\hline P3 & Partially equilibrated & Sulfated type & $\begin{array}{l}\text { Chlorinated sodium and calcium } \\
\text { Sulfated sodium and potassium }\end{array}$ \\
\hline $\mathrm{P} 4$ & Partially equilibrated & Sulfated type & $\begin{array}{l}\text { Chlorinated sodium and calcium } \\
\text { Sulfated sodium and potassium }\end{array}$ \\
\hline P5 & Partially equilibrated & Sulfated type & $\begin{array}{l}\text { Sodium chloride and potassium } \\
\text { Sulfated magnesium }\end{array}$ \\
\hline P6 & Magnesium type & Sulfated type & Sodium chloride and magnesium \\
\hline P7 & Magnesium type & Sulfated type & Sodium chloride and magnesium \\
\hline P8 & Partially equilibrated & Slightly sulfated & Mildly sulfated \\
\hline P9 & Partially equilibrated & Slightly bicarbonated & Mildly bicarbonate \\
\hline P10 & Partially equilibrated & Sulfated type & Chloride and sulfated calcium \\
\hline P11 & Partially equilibrated & Sulfated type & $\begin{array}{l}\text { Sodium chloride and potassium } \\
\text { Sulfated magnesium }\end{array}$ \\
\hline P12 & Calcium type & Sulfated type & Chloride and sulfated calcium \\
\hline P13 & Magnesium type & Sulfated type & $\begin{array}{l}\text { Sodium chloride and potassium } \\
\text { Sulfated magnesium }\end{array}$ \\
\hline P14 & Partially equilibrated & Sulfated type & $\begin{array}{l}\text { Sodium chloride and potassium } \\
\text { Sulfated magnesium }\end{array}$ \\
\hline P15 & Partially equilibrated & Sulfated type & $\begin{array}{l}\text { Sodium chloride and potassium } \\
\text { Sulfated magnesium }\end{array}$ \\
\hline P16 & Partially equilibrated & Sulfated type & $\begin{array}{c}\text { Sodium chloride and potassium } \\
\text { Sulfated magnesium }\end{array}$ \\
\hline $\mathrm{P} 17$ & Partially equilibrated & Sulfated type & Chloride-type calcium and sulfated magnesium \\
\hline
\end{tabular}

however, since they are sulfated acid with $\mathrm{pH}<2$, they would favor this dissolution and their high presence, as it is observed in Tables 3 and 4.

On the other hand, the vapors of geothermal systems, which flow through the fractures, heat the underground waters. In this case, it is observed that the P8 (COCI) source is located in heated vapor waters and, as a consequence, it has low concentrations of $\left(\mathrm{SO}_{4}\right)^{2-}$ as it is observed in Figure 5(b). Finally, the P9 (COPT) source belongs to the peripheral waters which are characterized for being waters that, although they have interacted with the rocks, have not reached the equilibrium with these rocks, and they are characterized for having a low contribution of $\mathrm{HCO}_{3}^{-}$and a neutral $\mathrm{pH}$, as it is observed in Figure 5(c).

The $\mathrm{HCO}_{3}^{-}$and other ionic species originated from the mixture between $\mathrm{CO}_{2}$ and $\mathrm{H}_{2} \mathrm{O}$. Based on the above, values of $15.2 \mathrm{ppm}$ and $14.0 \mathrm{ppm}$ of $\mathrm{HCO}_{3}^{-}$for the $\mathrm{P} 8$ and $\mathrm{P} 9$ fountains are observed in Table 3 . This is because this species is stable at $\mathrm{pH}$ between 5.5 and 8.0, and this is the reason why only these two fountains present values of $\mathrm{HCO}_{3}^{-}$. In the other fountains, values of $0.0 \mathrm{ppm}$ of $\mathrm{HCO}_{3}^{-}$are observed, due to the high temperatures and to the fact that at $\mathrm{pH}$ between 3 and 1, the formation of $\mathrm{HCO}_{3}^{-}$is inhibited [32]. However, some fountains like P10, P12, P13, and P14 present temperatures below $20^{\circ} \mathrm{C}$ (Table 4 ).
4.3. $\mathrm{Na}^{+}-\mathrm{K}^{+}-\mathrm{Mg}^{2+}$ Diagram. This diagram allows establishing a physicochemical equilibrium between the water-rock interaction and temperatures of the geothermal reservoirs [42], thus allowing the study of the maturity of the waters by means of the principal cations $\mathrm{Na}^{-}-\mathrm{K}^{+}-\mathrm{Mg}^{2+}$ [39].

Figure 8 shows that all the sources tend to be close to $\mathrm{Mg}^{2+}$, which indicates that the upwellings of the Puracé-La Mina sector are immature waters and that they have not reached the chemical equilibrium. Likewise, Giggenbach mentions that this type of waters is not suitable for evaluating the temperature by means of the $\mathrm{Na} / \mathrm{K}$ relationship [39]. This indicates that these waters do not interact with the rocks for a sufficient amount of time.

According to the $\mathrm{K} / \mathrm{Mg}$ geothermometer [39] (equation (1)), it is indicated that, for the sector of COMI and P14, the temperature oscillates between 71.61 and $91.61^{\circ} \mathrm{C}$.

$$
t=\frac{4410}{13.95-\log \left(\mathrm{K}^{2} / \mathrm{Mg}\right)}-273.15
$$

For subsequent studies, it is recommended to measure the geothermal gradient in order to establish the depth of the reservoir in such a way that more information can be found about the recharge area and the main structures that control the ascent to the surface, since some sources have 


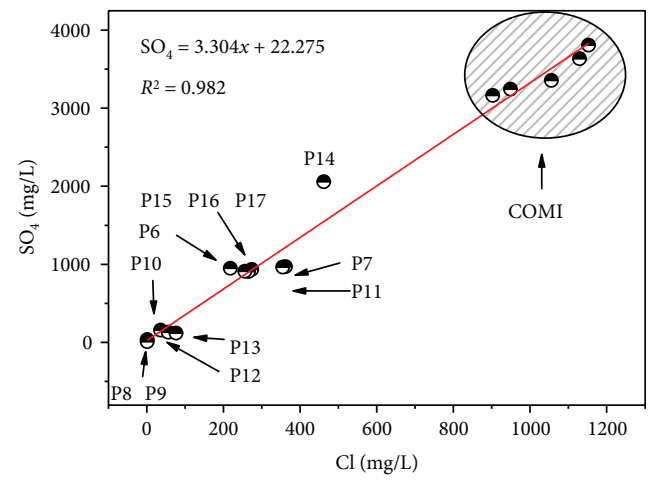

(a)
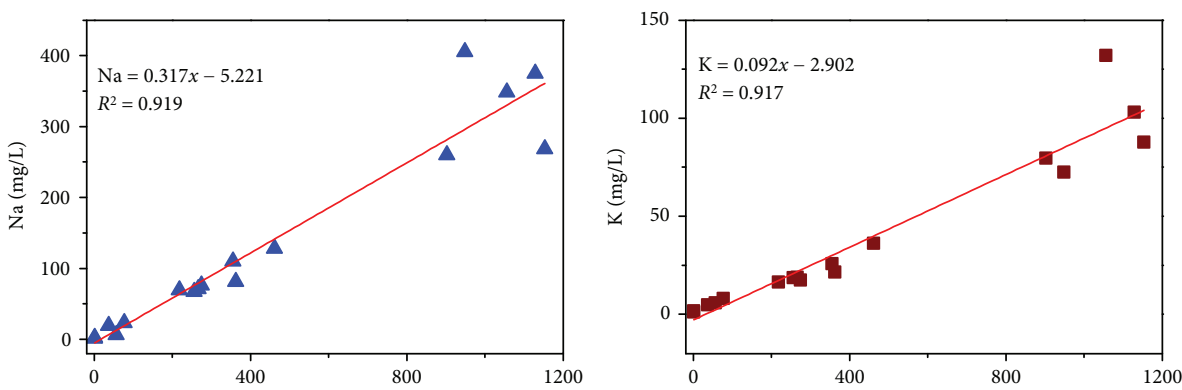

$\Delta \mathrm{Na}$
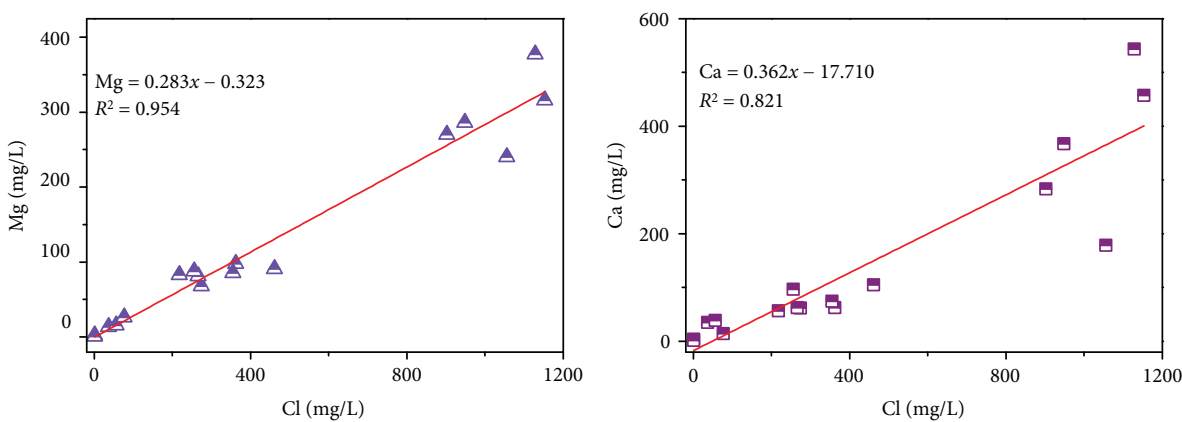

$\Delta \mathrm{Mg}$

E $\mathrm{Ca}$

(b)

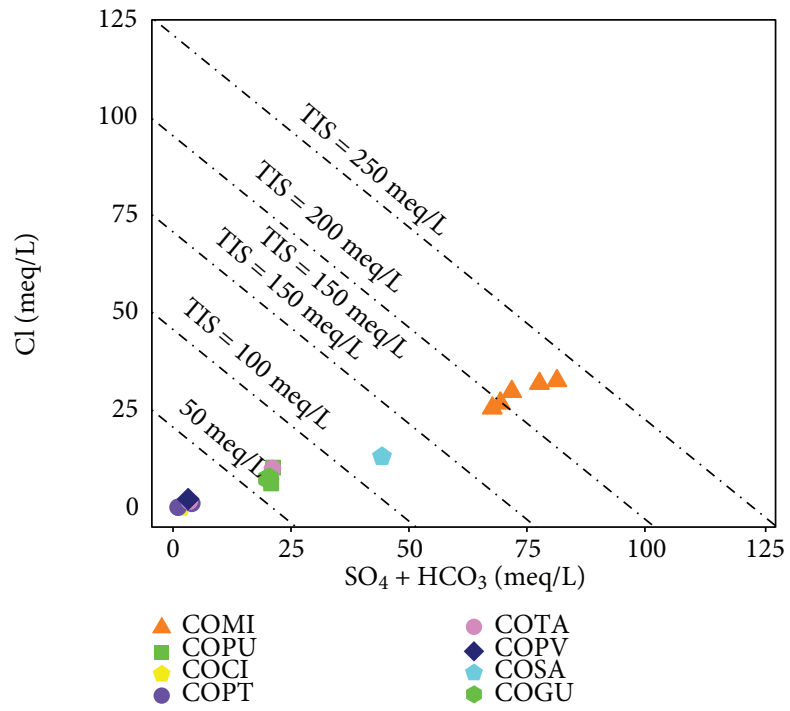

(c)

FIgure 6: Correlation plots: (a) $\mathrm{Cl}_{\text {vs }} \mathrm{SO}_{4}$, (b) $\mathrm{Cl}$ vs $\mathrm{Na}, \mathrm{K}$, and $\mathrm{Mg}$, and (c) total ionic salinity (TIS) lines. 


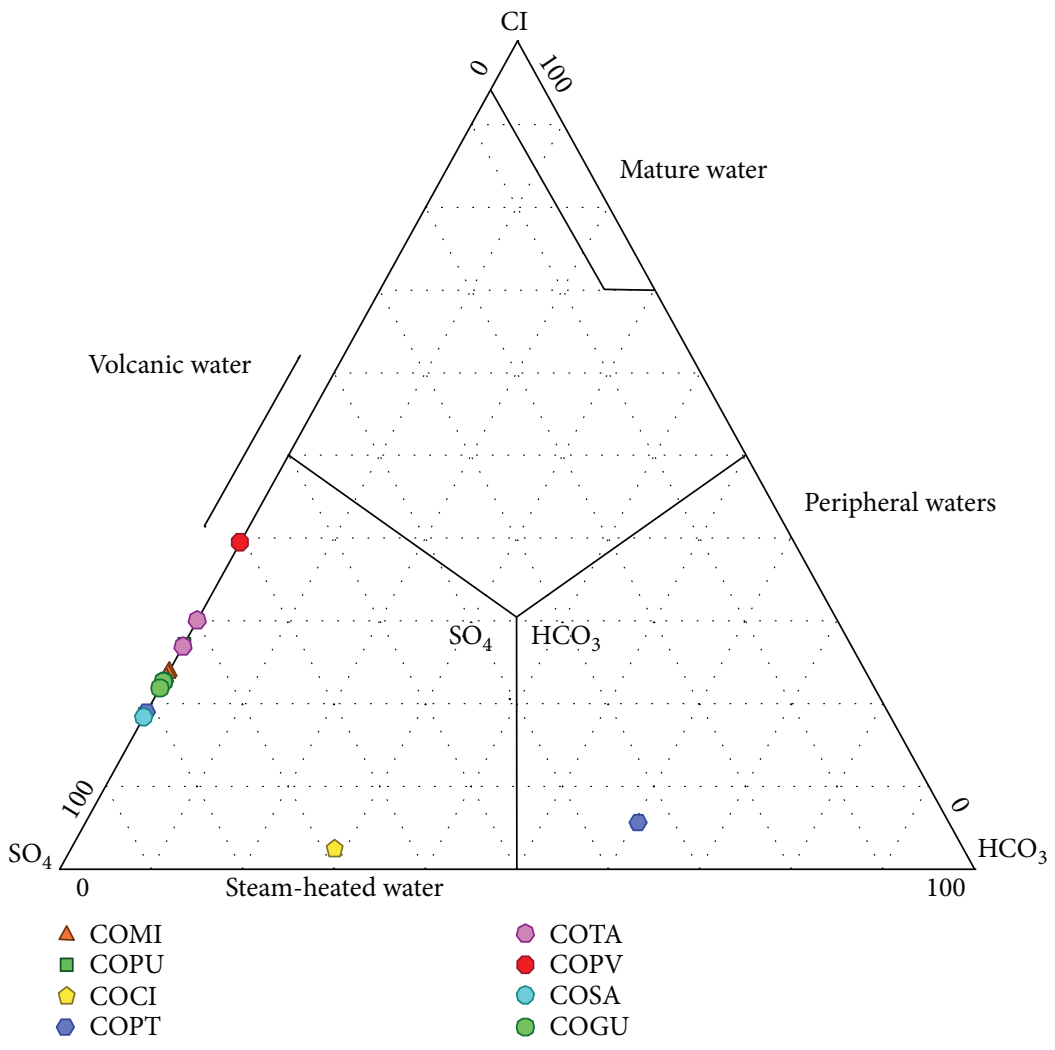

FIgURE 7: Ternary diagram of anions for the sources in Puracé-La Mina [39].

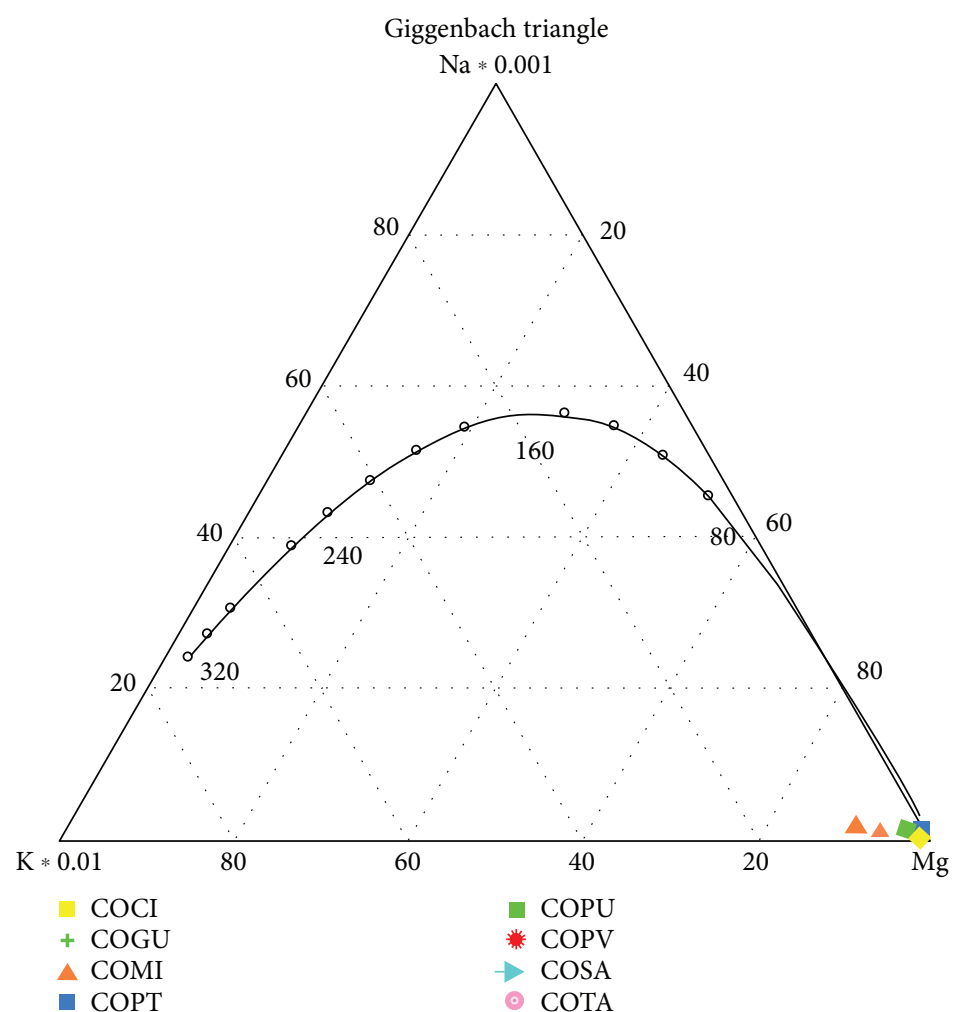

FIgURE 8: Ternary diagram of cations for the sources in Puracé-La Mina [39]. 


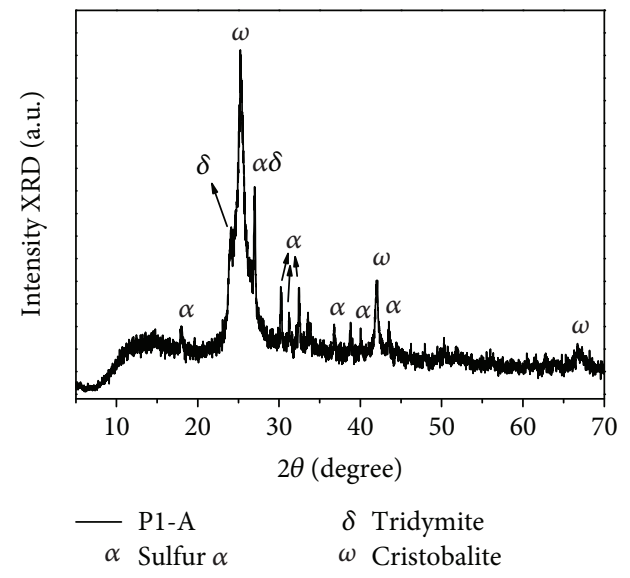

(a)

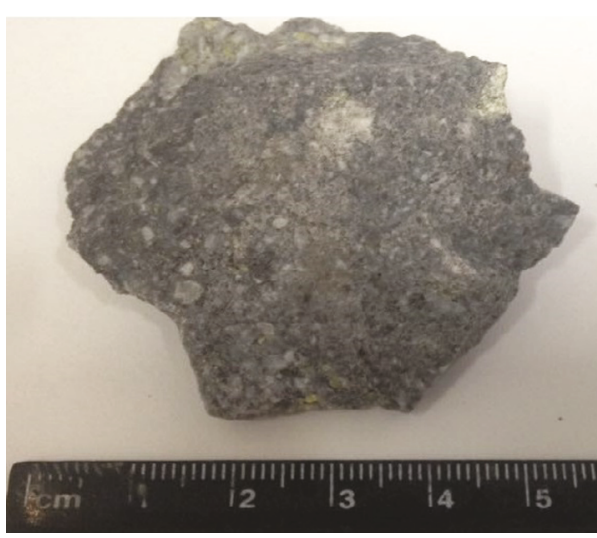

(b)

Figure 9: Sample P1-A (a) XRD patterns and (b) rock sample of crystalline tuff.

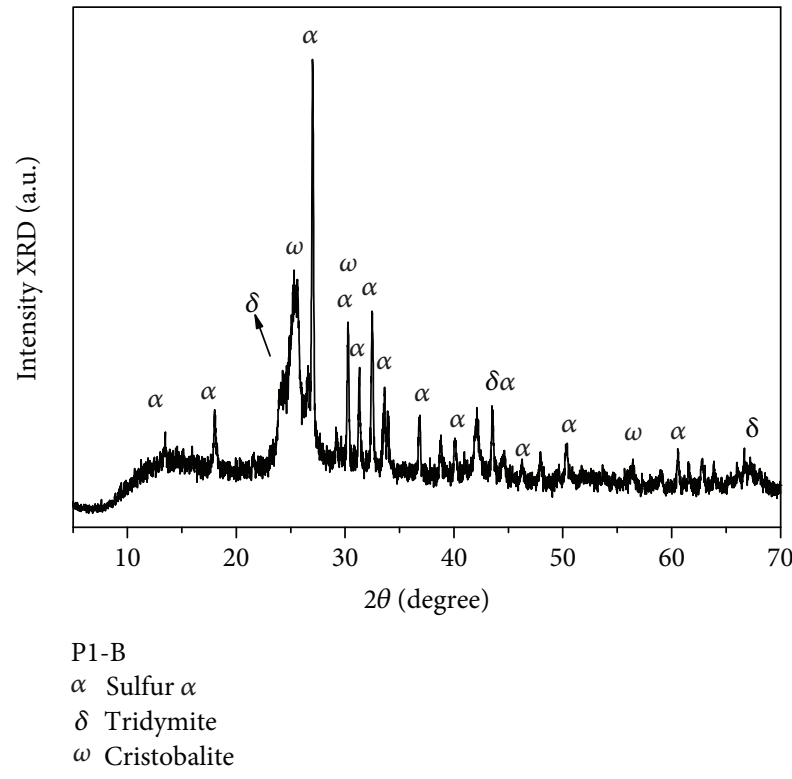

(a)

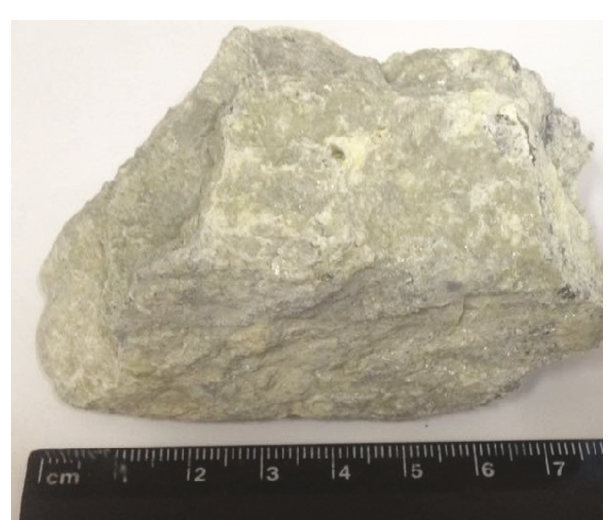

(b)

Figure 10: Sample P1-B (a) XRD patterns and (b) rock sample of crystalline tuff.

been little studied and this type of studies have not been reported in the literature.

4.4. Mineralogical characterization. XRD results and the analysis of the macroscopic description of the samples show that the P1-A sample (Figures $9(\mathrm{a})$ and $9(\mathrm{~b})$ ) is a dark-gray-colored rock with inlays of white minerals, white subtranslucent, somewhat tabular, light yellow crystals, and lithic black volcanic rock type (crystalline tuff). The P1-B sample (Figures 10(a) and 10(b)) is volcanic ash composed of silica with high sulfur mineralization of volcanic rock type (crystalline tuff). The P2-A sample (Figures 11(a) and 11(b)) is a medium gray to dark-gray-colored rock with silica isomorphs such as cristobalite, tridymite, and sulfur of volcanic rock type (crystalline tuff). The P2-B sample (Figures 12(a) and $12(\mathrm{~b})$ ) is a volcanic rock (crystalline tuff) with white and yellow crystals. The P3-A sample (Figures 13(a) and 13(b)) is a volcanic rock (crystalline tuff) with titanium mineralization (black). The P3-B sample (Figures 14(a) and $14(\mathrm{~b}))$ is a volcanic rock (breccia). The P10-A sample (Figures 15(a) and 15(b)) presents a variety of minerals such as cristobalite, tridymite, and albite; the latter being the one present at the highest proportion, and the rock type is a crystalline weathered tu with iron oxides. 

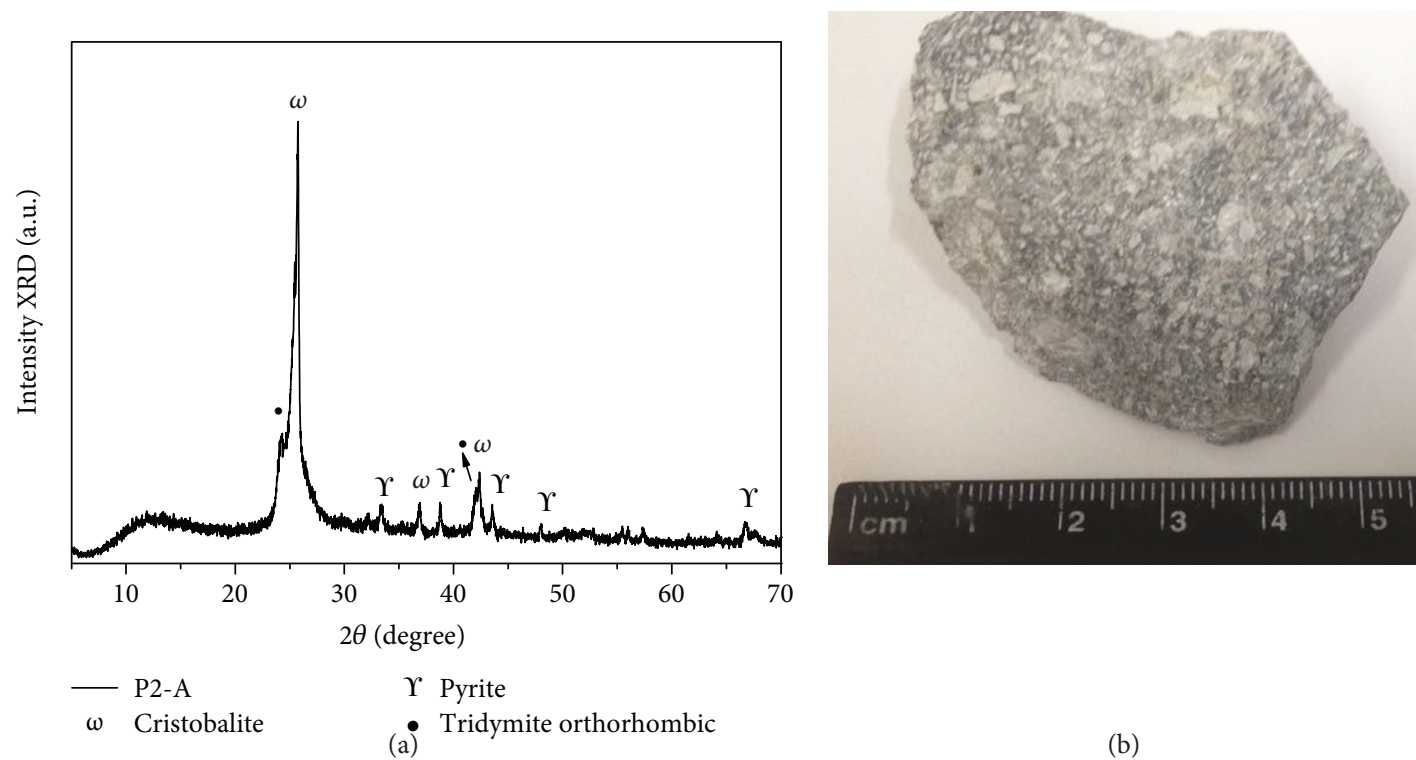

FIgURe 11: Sample P2-A (a) XRD patterns and (b) rock sample of crystalline tuff.

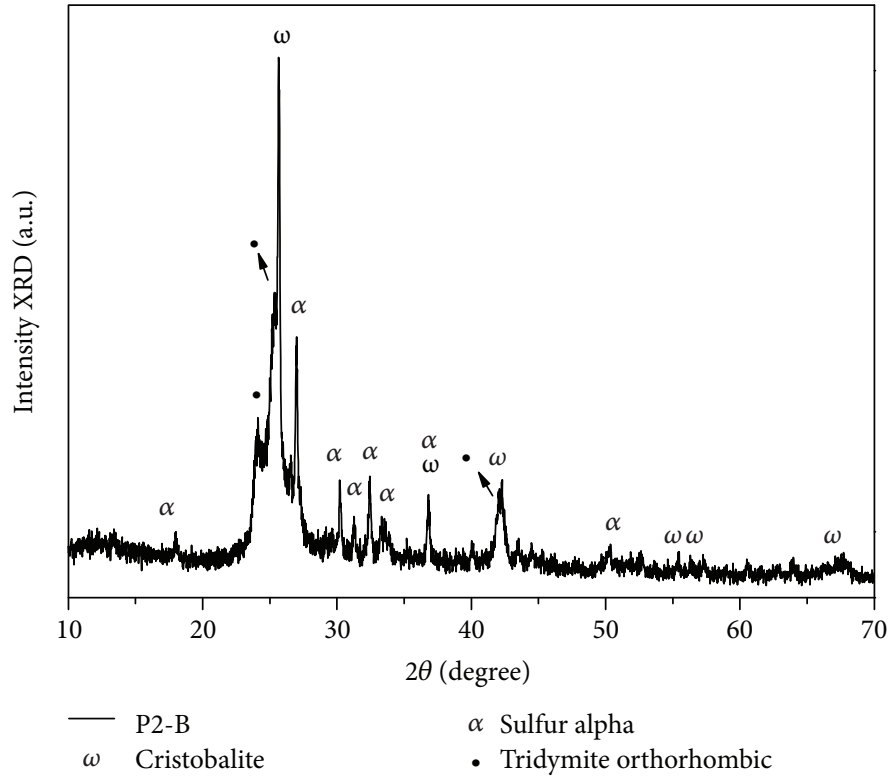

(a)

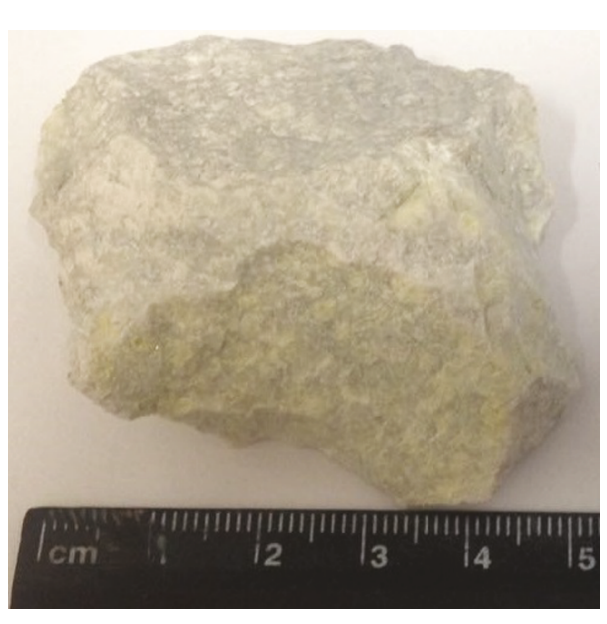

(b)

FIgURE 12: Sample P2-B (a) XRD patterns and (b) rock sample of crystalline tuff.

In samples $\mathrm{P} 1, \mathrm{P} 2$, and $\mathrm{P} 3$, the presence of a $\mathrm{TiO}_{2}$ anatase phase is observed. Ramos et al. [43] relate Ti- and Fe-based compounds with the titanomagnetite mineral whose $\mathrm{Fe}$ leaching is not favored at $\mathrm{pH}$ above 5 . However, in sources $\mathrm{P} 1, \mathrm{P} 2$, and $\mathrm{P} 3$, with $\mathrm{pH}$ values under $2: 21$ and temperatures of $40^{\circ} \mathrm{C}$ (Table 4), iron leaching is favored as a consequence of water-rock interaction, generating an increase in the $\mathrm{TiO}_{2}$ phase in the form of anatase and rutile.

Tables 8 and 7 show that the samples are mostly composed of $\mathrm{SiO}_{2}, \mathrm{Al}_{2} \mathrm{O}_{3}$, and $\mathrm{SO}_{3}$. On the other hand, $\mathrm{Ti}$ and $\mathrm{Fe}$ oxides are observed with concentrations lower than $81 \mathrm{ppm}$ in the P1, P2, and P3 fountains, and lower than <IDL in P10. As mentioned earlier, Fe solubility is subjected to temperature and mainly to the $\mathrm{pH}$ [43]. Titanium analysis was not carried out in this study.

\section{Discussion}

5.1. Changes in $p H$ and Error Charge Imbalance. Taking into account that the zone of study considered in this work (Puracé-La Mina) presents sources with $\mathrm{pH}$ between 2 and 4 for the majority of sources and $\left(\mathrm{SO}_{4}\right)^{2-}$ ion as the 


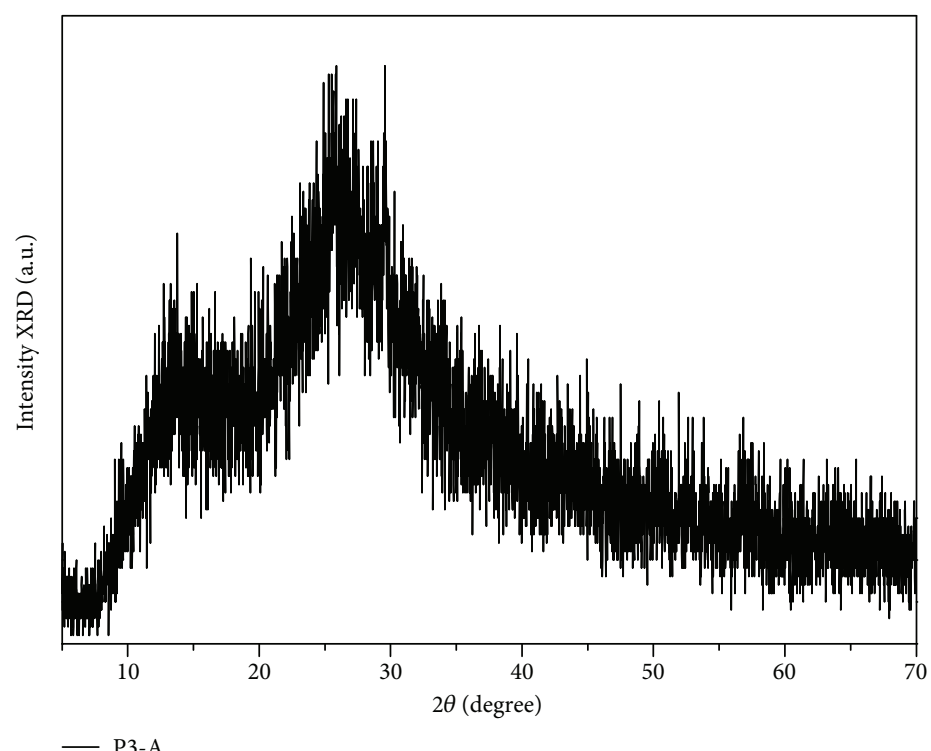

(a)

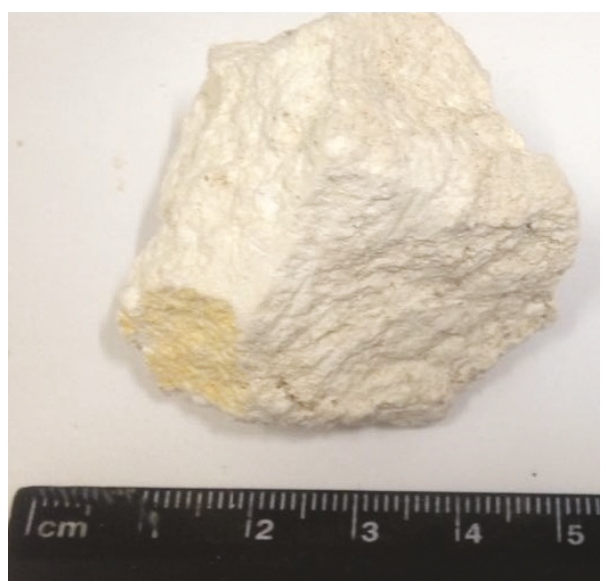

(b)

FIGURE 13: Sample P3-A (a) XRD patterns and (b) sample of breccia.

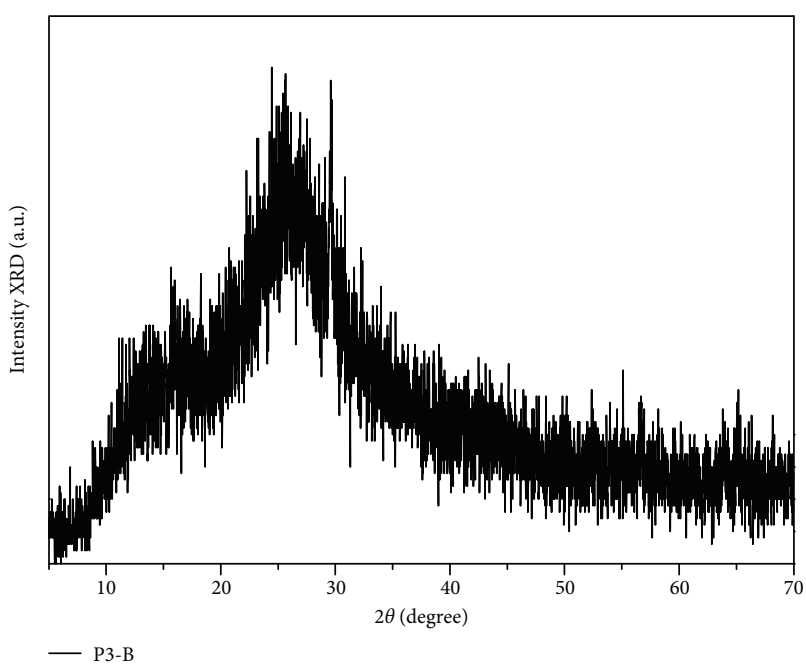

(a)

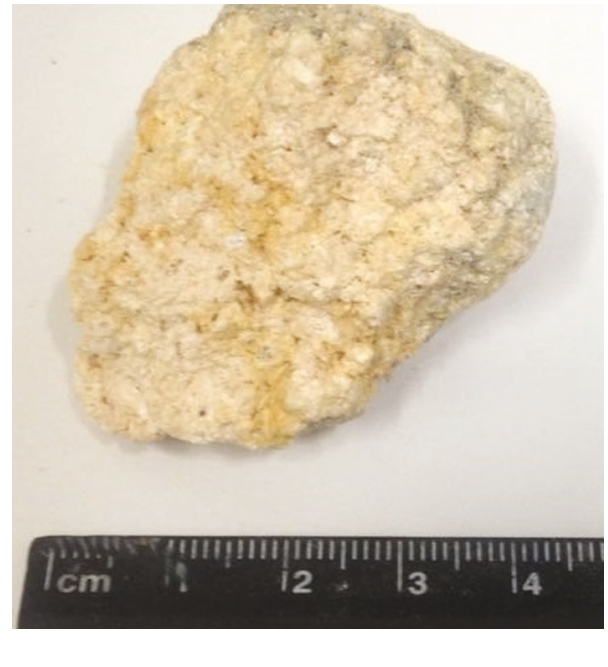

(b)

FIgURe 14: Sample P3-B (a) XRD patterns and (b) rock sample of crystalline tuff.

major component, error in charge imbalance can be attributed to the oxidation of compounds and elements as $\mathrm{Fe}$, $\mathrm{H}_{2} \mathrm{~S}$, and $\mathrm{S}_{2} \mathrm{O}_{3}$, and the degassing of $\mathrm{CO}_{2}$ and the decrement of temperature. In this case, it is important to consider that during hydrolysis and oxidation reactions processes, free $\mathrm{H}^{+}$ion can be considered as a main cation with $\mathrm{pH}<2.5$. In order to verify the abovementioned results, Nordstrom carried out a test related to how $\left(\mathrm{S}_{2} \mathrm{O}_{3}\right)^{2-}$ oxidation affected the water chemistry [44]. During this process, it was also observed how the oxidation of thiosulfate would produce considerable amounts of $\left(\mathrm{SO}_{4}\right)^{2-}$ ion, which can result in an important imbalance in ion balance. On the other hand, the increment in temperature can cause a major difference in $\mathrm{pH}$. Additional to this, it is important to consider the next chemical reactions $[44,45]$ :

$$
\begin{array}{ll}
\mathrm{HSO}_{4}^{-} \leftrightarrow \mathrm{H}^{+}+\mathrm{SO}_{4}^{2-} & (p K=1.98) \\
\mathrm{Fe}^{2+}+\frac{1}{2} \mathrm{O}_{2} \mathrm{H}^{+} \leftrightarrow \mathrm{Fe}^{3+}+\frac{1}{2} \mathrm{H}_{2} \mathrm{O} & (p K=7.77) \\
\mathrm{Fe}^{3+}+\mathrm{H}_{2} \mathrm{O} \leftrightarrow \mathrm{FeOH}^{2+}+\mathrm{H}^{+} & \left(p K_{1}=2.19\right) \\
\mathrm{Al}^{3+}+\mathrm{H}_{2} \mathrm{O} \leftrightarrow \mathrm{Al}(\mathrm{OH}) \frac{0}{3} \mathrm{H}^{+} & \left(p K_{1}=6.93\right) \\
\mathrm{AlOH}^{2+}+\mathrm{H}_{2} \mathrm{O} \leftrightarrow \mathrm{Al}(\mathrm{OH}) \frac{+}{2} \mathrm{H}^{+} & \left(p K_{2}=5.10\right) \\
\mathrm{Al}(\mathrm{OH}) \frac{+}{2}+\mathrm{H}_{2} \mathrm{O} \leftrightarrow \mathrm{Al}(\mathrm{OH}) \frac{0}{3} \mathrm{H}^{+} & \left(p K_{3}=6.70\right)
\end{array}
$$




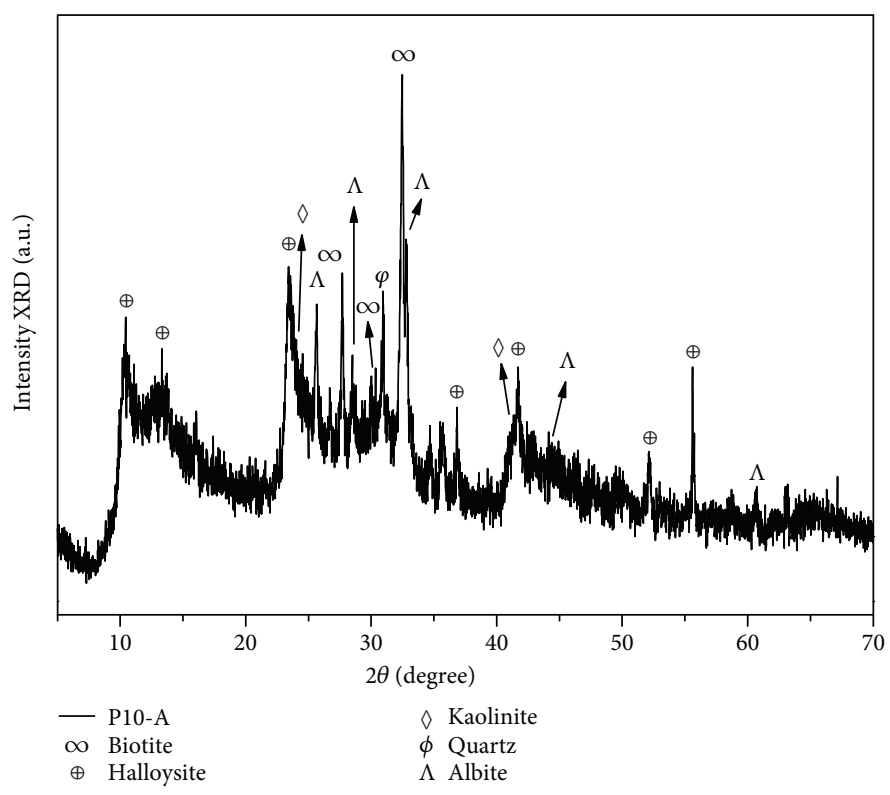

(a)

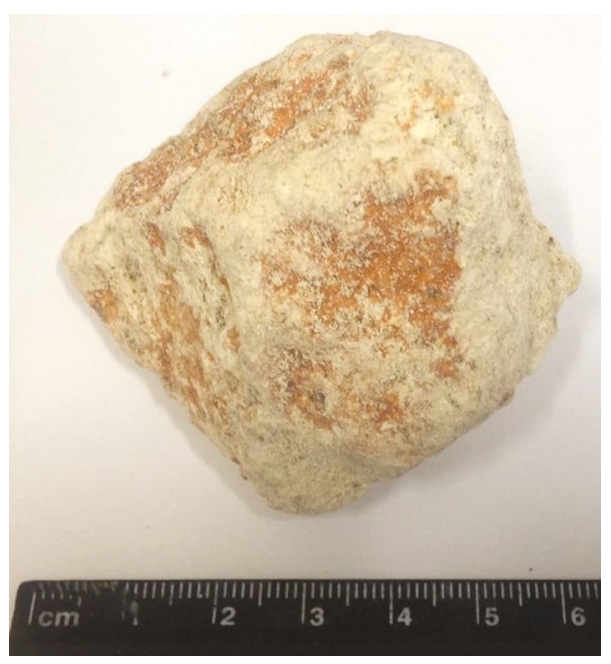

(b)

Figure 15: Sample P10-A (a) XRD patterns and (b) rock sample of kaolinite (arcillocite).

Table 6: Minerals in samples from the Puracé-La Mina sector.

\begin{tabular}{|c|c|c|c|c|c|c|c|c|}
\hline Minerals & Chemical formula & P1-A & P1-B & P2-A & P2-B & P3-A & P3-B & P1O-A \\
\hline Cristobalite & $\mathrm{SiO}_{2}$ & 48 & 45 & 69 & 43 & 58 & 62 & - \\
\hline Tridymite & $\mathrm{SiO}_{2}$ & 32 & 16 & 27 & 32 & - & - & - \\
\hline Sulfur & S & 20 & 39 & - & 25 & - & - & - \\
\hline Pyrite & $\mathrm{Fe}_{2} \mathrm{O}_{3}$ & - & - & 4 & - & - & - & - \\
\hline Gypsum & $\mathrm{CaSO}_{4} * 2 \mathrm{H}_{2} \mathrm{O}$ & - & - & - & - & 24 & 25 & - \\
\hline Anatase & $\mathrm{TiO}_{2}$ & - & - & - & - & 18 & 13 & - \\
\hline Quartz & $\mathrm{SiO}_{2}$ & - & - & - & - & - & - & 4 \\
\hline Halloysite & $\mathrm{Al}_{2} \mathrm{Si}_{2} \mathrm{O}_{5}(\mathrm{OH})_{4} * 2 \mathrm{H}_{2} \mathrm{O}$ & - & - & - & - & - & - & 10 \\
\hline Koalinite & $\mathrm{Al}_{2} \mathrm{Si}_{2} \mathrm{O}_{5}(\mathrm{OH})_{4}$ & - & - & - & - & - & - & 27 \\
\hline Biotite & $\mathrm{K}(\mathrm{Mg}, \mathrm{Fe})_{3} \mathrm{AlSi}_{3} \mathrm{O}_{10}(\mathrm{OH}, \mathrm{F})_{2}$ & - & - & - & - & - & - & 8 \\
\hline Albite & $\mathrm{NaAlSi}_{3} \mathrm{O}$ & - & - & - & - & - & - & 51 \\
\hline
\end{tabular}

Finally, when $\mathrm{pH}<3$, ion $\mathrm{H}^{+}$percentage in meq increases in a such a way that at $\mathrm{pH}<2.2$, it can represent the $50 \%$ in moles of the total ions. In addition, this can lead to an increment in $\left(\mathrm{SO}_{4}\right)^{2-}$ concentration approaching the pure $\mathrm{H}_{2} \mathrm{SO}_{4}$ line and $\mathrm{Fe}$ and $\mathrm{Al}$ ions are dominant.

Some sources were compared with more recent records reported by INGEOMINAS in the case of the La Mina 1 source, and similar values are observed in $\mathrm{pH}$ (difference of \pm 0.2$)$, concentration of $\left(\mathrm{SO}_{4}\right)^{2-}, \mathrm{Cl}^{-}$with sources $\mathrm{P} 1$ and $\mathrm{P} 2$, with a difference of $\pm 140 \mathrm{ppm}$, and similarity in the Piper and Stiff diagrams. The Guarquelló source presents similarity (Pipper and Stif diagrams) with the sources $\mathrm{P} 15, \mathrm{P} 16$, and P17. However, an increase in the $\left(\mathrm{SO}_{4}\right)^{2-}$ ions is observed, which indicates that during the time elapsed from the taking of the sample and the measurement in the laboratory, there was an increase in the concentration of
$\left(\mathrm{SO}_{4}\right)^{2-}$, thus generating an imbalance in the ion charge. Finally, the sources P8 and P9 showed a charge imbalance $>20 \%$, which was due to the addition among ions that was less than $1.5 \mathrm{meq} / \mathrm{L}$.

5.2. Thermal Water. The absorption of magmatic volatile products that prevails in groundwater leads to the formation of reactive substances. In the magmatic vapor phase, $\mathrm{SO}_{2}$ is one the main components that, when interacting with $\mathrm{H}_{2} \mathrm{O}$, is transformed into $\mathrm{H}_{2} \mathrm{~S}$ and $\left(\mathrm{SO}_{4}\right)^{2-}$ (equation (3)). Then, the oxidation of $\mathrm{H}_{2} \mathrm{O}$ to $\left(\mathrm{SO}_{4}\right)^{2-}$ by atmospheric $\mathrm{CO}_{2}$ and gas vapors present in the surface waters lead to the formation of sulfated-acid waters with high concentrations of $\left(\mathrm{SO}_{4}\right)^{2-}$ (equation (4)) [32] and $\mathrm{Cl}^{-}$ions $[16,46]$. Another issue to take into account, concerning the high concentration of $\left(\mathrm{SO}_{4}\right)^{2-}$ ions in the Puracé-La Mina sector, is the closeness 
TABLe 7: XRF analysis of La Mina samples (a) P1-A, (b) P1-B, and (c) P2-A

(a)

\begin{tabular}{lc}
\hline Element compound & P1-A (\%) wt \\
\hline $\mathrm{SiO}_{2}$ & 56.15 \\
$\mathrm{SO}_{3}$ & 41.30 \\
$\mathrm{Fe}_{2} \mathrm{O}_{3}$ & 1.74 \\
$\mathrm{TiO}_{2}$ & 0.42 \\
$\mathrm{Ba}$ & 0.11 \\
$\mathrm{Al}_{2} \mathrm{O}_{3}$ & 0.07 \\
$\mathrm{Cl}$ & 0.06 \\
$\mathrm{Ce}$ & 0.03 \\
$\mathrm{Na}{ }_{2} \mathrm{O}$ & 0.02 \\
$\mathrm{MgO}$ & 0.02 \\
$\mathrm{CaO}$ & 0.02 \\
$\mathrm{Cr}$ & 0.02 \\
$\mathrm{Zr}$ & $82 \mathrm{ppm}$ \\
$\mathrm{K}_{2} \mathrm{O}$ & $81 \mathrm{ppm}$ \\
$\mathrm{MnO}$ & $70 \mathrm{ppm}$ \\
$\mathrm{P}$ & $\mathrm{O}_{5}$ \\
$\mathrm{Nb}$ & $51 \mathrm{ppm}$ \\
$\mathrm{Cu}$ & $48 \mathrm{ppm}$ \\
$\mathrm{Se}$ & $40 \mathrm{ppm}$ \\
\hline
\end{tabular}

(b)

\begin{tabular}{lc}
\hline Element compound & P1-B (\%) wt \\
\hline $\mathrm{SO}_{3}$ & 72.14 \\
$\mathrm{SiO}_{2}$ & 26.47 \\
$\mathrm{Fe}_{2} \mathrm{O}_{3}$ & 0.91 \\
$\mathrm{TiO}_{2}$ & 0.33 \\
$\mathrm{Ba}$ & 0.07 \\
$\mathrm{Al}_{2} \mathrm{O}_{3}$ & 0.03 \\
$\mathrm{Cl}$ & 0.02 \\
$\mathrm{Ce}$ & $98 \mathrm{ppm}$ \\
$\mathrm{CaO}$ & $77 \mathrm{ppm}$ \\
$\mathrm{W}$ & $69 \mathrm{ppm}$ \\
$\mathrm{Zr}$ & $46 \mathrm{ppm}$ \\
$\mathrm{Bi}$ & $43 \mathrm{ppm}$ \\
$\mathrm{Pb}$ & $35 \mathrm{ppm}$ \\
$\mathrm{Cu}$ & $22 \mathrm{ppm}$ \\
$\mathrm{Se}$ & $20 \mathrm{ppm}$ \\
$\mathrm{Sr}$ & $15 \mathrm{ppm}$ \\
$\mathrm{Nb}$ & $10 \mathrm{ppm}$ \\
\hline
\end{tabular}

(c)

\begin{tabular}{lc}
\hline Element compound & P2-A (\%) wt \\
\hline $\mathrm{SiO}_{2}$ & 85.56 \\
$\mathrm{SO}_{3}$ & 9.27 \\
$\mathrm{Fe}_{2} \mathrm{O}_{3}$ & 3.50 \\
\hline
\end{tabular}

TABle 7: Continued.

\begin{tabular}{lc}
\hline Element compound & P2-A (\%) wt \\
\hline $\mathrm{TiO}_{2}$ & 0.86 \\
$\mathrm{Ba}$ & 0.25 \\
$\mathrm{Al}_{2} \mathrm{O}_{3}$ & 0.22 \\
$\mathrm{Cl}$ & 0.08 \\
$\mathrm{MgO}$ & 0.05 \\
$\mathrm{Na}_{2} \mathrm{O}$ & 0.04 \\
$\mathrm{CaO}$ & 0.03 \\
$\mathrm{Cr}$ & 0.02 \\
$\mathrm{Zr}$ & 0.02 \\
$\mathrm{Nb}$ & 0.02 \\
$\mathrm{MnO}$ & 0.01 \\
$\mathrm{P}_{2} \mathrm{O}_{5}$ & 0.01 \\
$\mathrm{~K}_{2} \mathrm{O}$ & 0.01 \\
$\mathrm{~Pb}$ & $80 \mathrm{ppm}$ \\
$\mathrm{Cu}$ & $51 \mathrm{ppm}$ \\
$\mathrm{Sr}$ & $29 \mathrm{ppm}$ \\
\hline
\end{tabular}

of the thermal sources to the Puracé volcano, which has been the source of S exploitation.

$$
\begin{gathered}
4 \mathrm{SO}_{2(a c)}+4 \mathrm{H}_{2} \mathrm{O}_{(l)} \leftrightarrow \mathrm{H}_{2} \mathrm{~S}_{(a c)}+3 \mathrm{H}_{2} \mathrm{SO}_{4(a c)} \\
\mathrm{H}_{2} \mathrm{~S}_{(a c)}+2 \mathrm{O}_{2(g)} \leftrightarrow 2 \mathrm{H}_{(a c)}^{+}+\left(\mathrm{SO}_{4}\right)_{(a c)}^{2-}
\end{gathered}
$$

Taking into account the high solubility of magmatic gases like $\mathrm{HCl}$ and $\mathrm{HF}$ [47], it can be inferred, based on Table 3, that there is a higher presence of magmatic gases of the $\mathrm{HCl}$ type, since the amount of $\mathrm{Cl}^{-}$ions are high.

5.3. Minerals. Considering the results shown in Table 6, a great variety of minerals composed of mainly $\mathrm{Si}, \mathrm{Fe}, \mathrm{Ti}$, $\mathrm{Al}$, and $\mathrm{S}$ are observed. In this way, rocks exposed to water can react under several agents being involved with physical and chemical alterations due to water absorption and resulting in the rupture of ionic bonds and hence in rock expansion. Similarly, hydrolysis processes lead to transformations in rocks giving special characteristics to the water. This is the reason why elements like $\mathrm{Na}, \mathrm{K}, \mathrm{Mg}$, and $\mathrm{Ca}$ exhibit high mobility and high concentration due to the leaching of minerals as igneous rhyolite $[16,38]$. An example of water-rock interactions is expressed in the following chemical reaction [48]:

$$
\mathrm{KAlSi}_{3} \mathrm{O}_{8}+\mathrm{H}_{2} \mathrm{O} \stackrel{\text { Hydrolysis }}{\longrightarrow} \mathrm{HAlSi}_{3} \mathrm{O}_{8}+\mathrm{K}^{+}+\mathrm{OH}^{-}
$$

Some metals which can be considered as health hazards are found in very low concentrations in both water and rocks including $\mathrm{Cr}, \mathrm{Zn}, \mathrm{Rb}, \mathrm{Sr}, \mathrm{Ba}, \mathrm{Ce}$, and Se. Some metals are not found in elementary form such as Cr. This element is generally found in the form of chromite $\left(\mathrm{FeCr}_{2} \mathrm{O}_{4}\right)$, in the oxidation state $\mathrm{Cr}^{6+}$ (most toxic form), and in crocoite $\left(\mathrm{PbCrO}_{4}\right)$. At $\mathrm{pH}<4$, its dominant form 
TABLe 8: XRF analysis of La Mina samples (a) P2-B, (b) P3-B, and (c) P10-A

(a)

\begin{tabular}{|c|c|}
\hline Element compound & P2-B (\%) wt \\
\hline $\mathrm{SiO}_{2}$ & 62.34 \\
\hline $\mathrm{SO}_{3}$ & 36.38 \\
\hline $\mathrm{TiO}_{2}$ & 0.63 \\
\hline $\mathrm{Al}_{2} \mathrm{O}_{3}$ & 0.19 \\
\hline $\mathrm{Fe}_{2} \mathrm{O}_{3}$ & 0.16 \\
\hline $\mathrm{Ba}$ & 0.09 \\
\hline $\mathrm{Na}_{2} \mathrm{O}$ & 0.06 \\
\hline $\mathrm{Cl}$ & 0.03 \\
\hline $\mathrm{MgO}$ & 0.03 \\
\hline $\mathrm{CaO}$ & 0.02 \\
\hline $\mathrm{K}_{2} \mathrm{O}$ & 0.02 \\
\hline $\mathrm{Ce}$ & 0.02 \\
\hline $\mathrm{Cr}$ & 0.01 \\
\hline $\mathrm{Zr}$ & 0.01 \\
\hline $\mathrm{MnO}$ & 0.01 \\
\hline $\mathrm{P}_{2} \mathrm{O}_{5}$ & $86 \mathrm{ppm}$ \\
\hline $\mathrm{Nb}$ & $83 \mathrm{ppm}$ \\
\hline $\mathrm{Sr}$ & $22 \mathrm{ppm}$ \\
\hline $\mathrm{Se}$ & $13 \mathrm{ppm}$ \\
\hline
\end{tabular}

(b)

\begin{tabular}{lc}
\hline Element compound & P3-B (\%) wt \\
\hline $\mathrm{SiO}_{2}$ & 93.44 \\
$\mathrm{TiO}_{2}$ & 3.05 \\
$\mathrm{Al}_{2} \mathrm{O}_{3}$ & 1.25 \\
$\mathrm{SO}_{3}$ & 0.97 \\
$\mathrm{Fe}_{2} \mathrm{O}_{3}$ & 0.66 \\
$\mathrm{Ba}$ & 0.23 \\
$\mathrm{CaO}$ & 0.08 \\
$\mathrm{~K}_{2} \mathrm{O}$ & 0.07 \\
$\mathrm{MgO}$ & 0.06 \\
$\mathrm{P}_{2} \mathrm{O}_{5}$ & 0.06 \\
$\mathrm{Na}$ & $\mathrm{O}$ \\
$\mathrm{Zr}$ & 0.03 \\
$\mathrm{Ce}$ & 0.03 \\
$\mathrm{~W}$ & 0.02 \\
$\mathrm{Cl}$ & 0.02 \\
$\mathrm{Cr}$ & 0.02 \\
$\mathrm{~Pb}$ & $93 \mathrm{ppm}$ \\
$\mathrm{Sr}$ & $64 \mathrm{ppm}$ \\
$\mathrm{Nb}$ & $60 \mathrm{ppm}$ \\
$\mathrm{Cu}$ & $39 \mathrm{ppm}$ \\
\hline
\end{tabular}

(c)

\begin{tabular}{lc}
\hline Element compound & P10-A (\%) wt \\
\hline $\mathrm{SiO}_{2}$ & 53.26 \\
$\mathrm{Al}_{2} \mathrm{O}_{3}$ & 35.34 \\
$\mathrm{Fe}_{2} \mathrm{O}_{3}$ & 3.42 \\
$\mathrm{TiO}_{2}$ & 2.21 \\
$\mathrm{Na}_{2} \mathrm{O}$ & 1.98 \\
$\mathrm{CaO}$ & 1.92 \\
$\mathrm{~K}_{2} \mathrm{O}$ & 0.66 \\
$\mathrm{SO}_{3}$ & 0.36 \\
$\mathrm{Ba}$ & 0.33 \\
$\mathrm{P}_{2} \mathrm{O}_{5}$ & 0.21 \\
$\mathrm{MgO}$ & 0.10 \\
$\mathrm{Sr}$ & 0.06 \\
$\mathrm{~V}$ & 0.05 \\
$\mathrm{Zr}$ & 0.04 \\
$\mathrm{MnO}$ & 0.02 \\
$\mathrm{Cl}$ & 0.02 \\
$\mathrm{Cu}$ & 0.02 \\
$\mathrm{Zn}$ & $52 \mathrm{ppm}$ \\
$\mathrm{Nb}$ & $37 \mathrm{ppm}$ \\
$\mathrm{Rb}$ & $23 \mathrm{ppm}$ \\
\hline
\end{tabular}

is $\mathrm{Cr}^{3+}$ (its less contaminating form). This element generally forms complexes with $\mathrm{Cl}^{-}, \mathrm{OH}^{-}, \mathrm{F}^{-}$, and $\left(\mathrm{SO}_{4}\right)^{2-}$. However, the $\mathrm{Cr}$ concentration in waters was below IDL (Table 4) [49].

For the sample P10-A, XRD results showed a high concentration of albite (Table 6). This mineral is mainly composed of $\mathrm{Na}, \mathrm{Al}, \mathrm{Si}, \mathrm{O}$, and traces of $\mathrm{Ca}$. According to the report of Apollaro et al. [50], albite presents high concentrations of metal traces as $\mathrm{Sr}, \mathrm{Fe}, \mathrm{Ba}$, and $\mathrm{Rb}$, among others; meanwhile, other elements are present in concentrations lower than $10 \mathrm{ppm}$. In this manner, for the analyzed samples, these metal traces measured by XRF are present in concentrations lower than those reported by Apollaro (Table 8), except Fe, which is present in the form of oxide $(3.42 \%)$.

Only for a sample corresponding to the P2-A source (Table 6) can the presence of pyrite $\left(\mathrm{Fe}_{2} \mathrm{O}_{3}\right)$ be observed as determined by XRD analysis, corresponding to the results obtained from XRF analysis (Tables 7 and 8). On the other hand, in other sources, there is a low percentage of the $\left(\mathrm{Fe}_{2} \mathrm{O}_{3}\right)$ phase, as shown in the XRF analysis. Nevertheless, there is no evidence in the results of the XRD analysis of this compound, being an indication that it can be in a low concentration or in an amorphous phase. Pyrite generally reacts with water and oxygen allowing the formation of sulfates [51] as evidenced in the following equation $[52,53]$ :

$$
\begin{aligned}
4 \mathrm{FeS}_{2}+15 \mathrm{O}_{2}+2 \mathrm{H}_{2} \mathrm{O} \leftrightarrow & 4 \mathrm{Fe}^{3+}+4\left(\mathrm{SO}_{4}\right)^{2-} \\
& +4 \mathrm{HSO}_{4}^{-}(\mathrm{pH} \simeq 2)
\end{aligned}
$$


The alteration of the minerals, considering the mobility when reacting with the reported water, would be described as follows: $\mathrm{Cl}>\mathrm{SO}_{4}>\mathrm{Ca}>\mathrm{Na}>\mathrm{Mg}>\mathrm{K}>\mathrm{SiO}_{2}>-$ $\mathrm{Fe}_{2} \mathrm{O}_{3}>\mathrm{Al}_{2} \mathrm{O}_{3}$. This would explain the high presence of $\mathrm{Cl}^{-}$and $\left(\mathrm{SO}_{4}\right)^{2-}$ ions in the fountains of the mine (P1, P2, and P3). For example $\mathrm{Cl}^{-}$, which is in low concentrations according to the XRF analysis, would have higher values in the water analyses [49].

\section{Conclusions}

The physicochemical characteristics of 17 sources of the Puracé-La Mina sector were analyzed by means of ternary diagrams allowing their classification based on the most representative ions. In this way, it was possible to classify the sources, observing that most of the water analyzed is of sulfated chloride type. These results are consistent with the interpretations of the Piper and Stiff diagrams since most of the sources have an acidic $\mathrm{pH}$ due to the high concentrations of $\left(\mathrm{SO}_{4}\right)^{2-}$ and $\mathrm{Cl}^{-}$ions.

The sources of the Puracé-La Mina are immature waters, and they have not reached the chemical equilibrium yet. This indicates that the sources have not interacted for a sufficient time with the rocks, and the sources have a volcanic origin, which is typical of volcanic geothermal systems associated with volcanoes. The P8 source is placed in heated vapor water with low thermal contributions, and the P9 source belongs to peripheral waters with low thermal contribution.

The correlations of $\mathrm{Cl}$ vs $\mathrm{Na}, \mathrm{K}, \mathrm{Mg}$, and Ca present values of $R^{2}>0.82$, indicating that the soluble salts prevail in the sector and that chloride-calcium type waters also prevail. The correlation of $\mathrm{Cl}$ vs $\mathrm{SO}_{4}$ contains values of $R^{2}>0.98$ , and the ratio of $\mathrm{Cl} / \mathrm{SO}_{4}$ is less than 0.65 , indicating that the waters of this sector do not interact with sufficiently deep regions to react with the rocks, which is consistent with the diagram of cations that show the immaturity of the waters.

Taking into account the characteristics such as low $\mathrm{pH}$, temperatures $\sim 30^{\circ} \mathrm{C}$, high concentration of $\left(\mathrm{SO}_{4}\right)^{2-}$, and the geographical location near the Puracé volcano, in the La Mina sector, the error in the charge balance of the sources exceeding $10 \%$ is a product of the oxidation of compounds such as $\mathrm{Fe}, \mathrm{H}_{2} \mathrm{~S}$, and $\mathrm{S}_{2} \mathrm{O}_{3}$, the degassing of $\mathrm{CO}_{2}$, and the decrease in temperature that generates an increase in $\mathrm{H}^{+}$ ions, which must be included as the main cation because, according to [44], $\mathrm{H}^{+}$ions can represent up to $50 \%$ by mole of total ions.

Chemical and mineralogical characterization showed the presence of $\mathrm{TiO}_{2}$ and $\mathrm{Fe}_{2} \mathrm{O}_{3}$ that can be associated to the titanomagnetite phase which has no solubility at $\mathrm{pH}>5$. Nevertheless, some sources of the analyzed territory have $\mathrm{pH}$ values in the order of 2 and temperatures of $40^{\circ} \mathrm{C}$, which favor iron leaching, justifying the presence of this metal in water for these sources. In this way, the hydrolysis processes are favored at low $\mathrm{pH}$ and high temperatures $\left(>30^{\circ} \mathrm{C}\right)$, producing transformations in rocks, and hence, elements like $\mathrm{Na}, \mathrm{K}, \mathrm{Mg}$, and $\mathrm{Ca}$ have high mobility and are present in high concentrations in water.
The composition of minerals and lytic oxides of volcanic type rock, crystalline tuff, and breccia are represented by the presence of several isomorphous minerals of silica $\mathrm{SiO}_{2}$ with accessories like $\mathrm{Ti}, \mathrm{Zr}$, and $\mathrm{Cr}$, which are at low concentrations and are not that important to determine the name of the rock.

\section{Data Availability}

The data used to support the findings of this study are included within the article. However, any additional information that is required may be acquired from the corresponding author upon request.

\section{Conflicts of Interest}

The authors declare that they have no conflicts of interest.

\section{Acknowledgments}

The authors gratefully acknowledge the financial support of the Dirección de Investigaciones Manizales (DIMA) Universidad Nacional de Colombia, in the framework of the project for the development of a technological environment "Termacolores in the Puracé Indigenous Reservation" (RIP) for research and innovation in the use of hot springs, mineral waters, and use of natural sulfur aimed at promoting tourism and well-being in the Department of Cauca "Desarrollo de un entorno tecnológico Termacolores en el resguardo indígena Puracé para la investigación e innovación en el uso de aguas termales, aguas minerales y aprovechamiento del azufre natural orientados a potenciar el turismo y bienestar en el Departamento del Cauca." (in English, "Development of a technological environment Termacolores in the Puracé indigenous reservation for research and innovation in the use of thermal waters, mineral waters, and natural sulfur utilization aimed at promoting tourism and well-being in the Department of Cauca").

\section{References}

[1] Q. Guo, Z. Pang, Y. Wang, and J. Tian, "Fluid geochemistry and geothermometry applications of the Kangding high-temperature geothermal system in eastern Himalayas," Applied Geochemistry, vol. 81, pp. 63-75, 2017.

[2] M. Yamada, J. Shoji, S. Ohsawa et al., "Hot spring drainage impact on fish communities around temperate estuaries in southwestern Japan," Journal of Hydrology: Regional Studies, vol. 11, pp. 69-83, 2017.

[3] F. Perri, L. Borrelli, G. Gullà, and S. Critelli, "Chemical and minero petrographic features of plio-pleistocene fine-grained sediments in Calabria, southern Italy," Italian Journal of Geosciences, vol. 133, no. 1, pp. 101-115, 2014.

[4] C. M. Prieto-Barajas, R. Alfaro-Cuevas, E. Valencia-Cantero, and G. Santoyo, "Effect of seasonality and physicochemical parameters on bacterial communities in two hot spring microbial mats from Araró, Mexico," Revista Mexicana de Biodiversidad, vol. 88, no. 3, pp. 616-624, 2017.

[5] A. Chabaane, B. Redhaounia, and H. Gabtni, "Combined application of vertical electrical sounding and $2 \mathrm{D}$ electrical 
resistivity imaging for geothermal groundwater characterization: Hammam Sayala hot spring case study (NW Tunisia)," Journal of African Earth Sciences, vol. 134, pp. 292-298, 2017.

[6] Y. Kikawada, T. Ono, K. Ogawa, M. Fukai, and T. Oi, "Chemical geothermometry studies on a geothermal system in Manza Hot Springs near Kusatsu-Shirane volcano, Japan," Procedia Earth and Planetary Science, vol. 17, pp. 253-256, 2017.

[7] C. Apollaro, I. Fuoco, G. Vespasiano et al., "Geochemical and mineralogical characterization of tremolite asbestos contained in the Gimigliano Mount Reventino Unit (Calabria, South Italy)," Journal of Mediterranean Earth Sciences, vol. 10, pp. 5-15, 2018.

[8] L. Marini, G. Ottonello, M. Canepa, and F. Cipolli, "Waterrock interaction in the Bisagno valley (Genoa, Italy): application of an inverse approach to model spring water chemistry," Geochimica et Cosmochimica Acta, vol. 64, no. 15, pp. 26172635, 2000.

[9] L. Marini and G. Ottonello, Atlante degli Acquiferi del Comune di Genova, I Alta Val Bisagno ed Alta Val Polcevera, Pacini, Pisa, 1997.

[10] D. M. Guido and K. A. Campbell, "Jurassic hot spring deposits of the Deseado Massif (Patagonia, Argentina): characteristics and controls on regional distribution," Journal of Volcanology and Geothermal Research, vol. 203, no. 1-2, pp. 35-47, 2011.

[11] C. G. Ramos, A. G. De Mello, and R. M. Kautzmann, “A preliminary study of acid volcanic rocks for stonemeal application," Environmental Nanotechnology, Monitoring \& Management, vol. 1-2, pp. 30-35, 2014.

[12] I. Megyesi, "Estudios sobre los depósitos de azufre en la mina de El Vinagre," Servicio Geológico Nacional-Ingeominas, vol. 10, pp. 109-160, 1962.

[13] G. Garzón, Catálogo De Fuentes Termales Del Suroccidente Colombiano, Ingeominas, 1997.

[14] S. Arnorsson, A. Stefansson, and J. O. Bjarnason, "Fluid-fluid interactions in geothermal systems," Reviews in Mineralogy and Geochemistry, vol. 65, no. 1, pp. 259-312, 2007.

[15] H. Ármannsson, "The fluid geochemistry of Icelandic high temperature geothermal areas," Applied Geochemistry, vol. 66, pp. 14-64, 2016.

[16] J. K. Björke, A. Stefánsson, and S. Arnórsson, “Surface water chemistry at Torfajökull, Iceland-quantification of boiling, mixing, oxidation and water-rock interaction and reconstruction of reservoir fluid composition," Geothermics, vol. 58, pp. 75-86, 2015.

[17] H. Kaasalainen and A. Stefánsson, "The chemistry of trace elements in surface geothermal waters and steam, Iceland," Chemical Geology, vol. 330-331, pp. 60-85, 2012.

[18] J. Gunnarsson-Robin, A. Stefánsson, S. Ono, and P. Torssander, "Sulfur isotopes in Icelandic thermal fluids," Journal of Volcanology and Geothermal Research, vol. 346, pp. 161-179, 2017.

[19] F. Armijo, D. Michele, and M. Giacomino, "Análisis de las aguas minerales de la provincia de Entre Ríos, Argentina," El termalismo Argentino, vol. 4, pp. 55-84, 2008.

[20] M. Corral, J. López, I. Muñoz, and G. Luis, Estudio de la Relación entre los Componentes Físico-Químicos de las Aguas Minerales y las Caracteristicas Geológicas de Galicia, Instituto Geológico y Minero de España, 2006.

[21] D. Chandrasekharam and J. Bundschuh, Low-Enthalpy Geothermal Resources for Power Generation, CRC Press, Leiden, 2008.
[22] Unidad de Planeación Minero Energética, "Utilización de la Energía Geotérmica Documento Descriptivo," Formulación de un programa básico de normalización para aplicaciones de energías alternativas y difusión, p. 49, 2003.

[23] E. Lozano, "Hot springs and geothermal energy in Colombia," Geothermics, vol. 17, no. 2-3, pp. 377-379, 1988.

[24] T. Simkin and S. Institution, Volcanoes of the World: A Regional Directory, Gazetteer, and Chronology of Volcanism During the Last 10000 Years, Hutchison Ross Publishing Company, 1981, https://books.google.com.co/books?id=G8_ BU6H-RpUC.

[25] N. C. Sturchio, S. N. Williams, and Y. Sano, "The hydrothermal system of Volcan Purace, Colombia," Bulletin of Volcanology, vol. 55, no. 4, pp. 289-296, 1993.

[26] V. Oppenheim, "The Volcano Purace," American Journal of Science, vol. 248, no. 3, pp. 171-179, 1950.

[27] J. J. Monsalve, Z. I. Galarza, M. Zuluaga, and C. A. Laverde, "Mapa de amenaza volcánica del volcán puracé actual (Cauca Colombia) segunda versión (2014). Memoria Bogotá, Octubre de 2014 proyecto investigación y monitoreo de la amenaza volcánica dirección de geoamenazas mapa de amenaza volcánica del volcán puracé," Tech. Rep. Servicio Geológico Colombiano, Bogotá, 2014, https://www2.sgc.gov.co/sgc/vol canes/VolcanPurace/Documents/Memoria_MapaAmenaza_ Purace.pdf.

[28] APHA, "Standard methods for examination of water and wastewater," pp. 5-16, 1998, https://store.awwa.org/store/ productdetail.aspx?productid=28493774.

[29] A. X. S. Bruker, EVA, Software, Karlsruhe, Germany, 2001.

[30] A. C. Coelho, TOPAS Academic, Software, Brisbane Australia, 2007.

[31] C. H. Gammons, S. A. Wood, F. Pedrozo et al., "Hydrogeochemistry and rare earth element behavior in a volcanically acidified watershed in Patagonia, Argentina," Chemical Geology, vol. 222, no. 3-4, pp. 249-267, 2005.

[32] M. A. Gaviria Reyes, M. R. Agusto, M. A. Trinelli, A. T. Caselli, M. dos Santos Afonso, and S. Calabrese, "Estudio hidrogeoquímico de las áreas termales del complejo volcánico Copahue Caviahue," Revista de la Asociacion Geologica Argentina, vol. 73, no. 2, pp. 256-269, 2016.

[33] B. Ladouche and P. Weng, "Hydrochemical assessment of the Rochefort marsh. Role of surface and groundwater in the hydrological functioning of the wetland," Journal of Hydrology, vol. 314, no. 1-4, pp. 22-42, 2005.

[34] F. Bahri, H. Saibi, and M.-E.-H. Cherchali, "Characterization, classification, and determination of drinkability of some Algerian thermal waters," Arabian Journal of Geosciences, vol. 4, no. 1-2, pp. 207-219, 2011.

[35] C. Apollaro, G. Vespasiano, F. Muto, R. de Rosa, D. Barca, and L. Marini, "Use of mean residence time of water, flow rate, and equilibrium temperature indicated by water geothermometers to rank geothermal resources. Application to the thermal water circuits of Northern Calabria," Journal of Volcanology and Geothermal Research, vol. 328, pp. 147158, 2016.

[36] G. Vespasiano, C. Apollaro, F. Muto, E. Dotsika, R. de Rosa, and L. Marini, "Chemical and isotopic characteristics of the warm and cold waters of the Luigiane Spa near Guardia Piemontese (Calabria, Italy) in a complex faulted geological framework," Applied Geochemistry, vol. 41, pp. 73-88, 2014. 
[37] M. E. Soltan, "Characterisation, classification, and evaluation of some ground water samples in upper Egypt," Chemosphere, vol. 37, no. 4, pp. 735-745, 1998.

[38] E. P. Joseph, N. Fournier, J. M. Lindsay, and T. P. Fischer, "Gas and water geochemistry of geothermal systems in Dominica, Lesser Antilles island arc," Journal of Volcanology and Geothermal Research, vol. 206, no. 1-2, pp. 1-14, 2011.

[39] W. F. Giggenbach, "Geothermal solute equilibria. Derivation of Na-K-Mg-Ca geoindicators," Geochimica et Cosmochimica Acta, vol. 52, no. 12, pp. 2749-2765, 1988.

[40] W. F. Giggenbach, "Relative importance of thermodynamic and kinetic processes in governing the chemical and isotopic composition of carbon gases in high-heatflow sedimentary basins," Geochimica et Cosmochimica Acta, vol. 61, no. 17, pp. 3763-3785, 1997.

[41] H. Ármannsson, "Application of geochemical methods," in Short Course VII on Exploration for Geothermal Resources, pp. 1-8, Elsevier B.V., 2007.

[42] X. Wang, G. L. Wang, H. N. Gan, Z. Liu, and D. W. Nan, "Hydrochemical characteristics and evolution of geothermal fluids in the Chabu high-temperature geothermal system, Southern Tibet," Geofluids, vol. 2018, Article ID 8532840, 15 pages, 2018.

[43] C. G. Ramos, X. Querol, M. L. S. Oliveira, K. Pires, R. M. Kautzmann, and L. F. S. Oliveira, "A preliminary evaluation of volcanic rock powder for application in agriculture as soil a remineralizer," Science of the Total Environment, vol. 512-513, pp. 371-380, 2015.

[44] D. Kirk Nordstrom, R. Blaine McCleskey, and J. W. Ball, "Sulfur geochemistry of hydrothermal waters in Yellowstone National Park IV acid sulfate waters," Applied Geochemistry, vol. 24, no. 2, pp. 191-207, 2009.

[45] D. K. Nordstrom and D. G. Archer, "Arsenic thermodynamic data and environmental geochemistry," in Arsenic in Ground Waterpp. 1-25, Kluwer Academic Publishers, Boston.

[46] J. Wrage, D. Tardani, M. Reich et al., "Geochemistry of thermal waters in the Southern Volcanic Zone, Chile-implications for structural controls on geothermal fluid composition," Chemical Geology, vol. 466, pp. 545-561, 2017.

[47] M. Agusto, F. Tassi, A. T. Caselli et al., "Gas geochemistry of the magmatic hydrothermal fluid reservoir in the Copahue Caviahue Volcanic Complex (Argentina)," Journal of Volcanology and Geothermal Research, vol. 257, pp. 44-56, 2013.

[48] N. C. Brady and R. R. Weil, "Organisms and Ecology of the Soil," The nature and properties of soil, vol. 11, pp. 328-360, 1996.

[49] V. T. Sepulveda, D. A. d. 1. R. Pérez, and J. A. Velasco Trejo, "Summary for policymakers," Climate Change 2013-The Physical Science Basis: Working Group I Contribution to the Fifth Assessment Report of the Intergovernmental Panel on Climate Change, Intergovernmental Panel on Climate Change, Ed., Cambridge University Press, Cambridge, 2005.

[50] C. Apollaro, L. Marini, T. Critelli et al., "Investigation of rock-to-water release and fate of major, minor, and trace elements in the metabasalt-serpentinite shallow aquifer of Mt. Reventino (CZ, Italy) by reaction path modelling," Applied Geochemistry, vol. 26, no. 9-10, pp. 1722-1740, 2011.

[51] L. F. O. Silva, M. Izquierdo, X. Querol et al., "Leaching of potential hazardous elements of coal cleaning rejects," Environmental Monitoring and Assessment, vol. 175, no. 1-4, pp. 109-126, 2011.
[52] J. D. Rimstidt and D. J. Vaughan, "Pyrite oxidation: a state-of-the-art assessment of the reaction mechanism," Geochimica et Cosmochimica Acta, vol. 67, no. 5, pp. 873-880, 2003.

[53] K. Sasaki, "Raman study of the microbially mediated dissolution of pyrite by Thiobacillus ferrooxidans," The Canadian Mineralogist, vol. 35, no. 4, pp. 999-1008, 1997.

[54] G. de Colombia, "IGAC Geoportal," http://ssiglwps.igac.gov. co/ssigl2.0/visor/galeria.req? mapaId=57.

[55] Servicio Geológico Colombiano, "Mapa Geológico de Colombia PLANCHA 365 Coconuco,” https://www2.sgc.gov.co/Progra masDeInvestigacion/Geociencias/Paginas/MapaGeologico. aspx. 

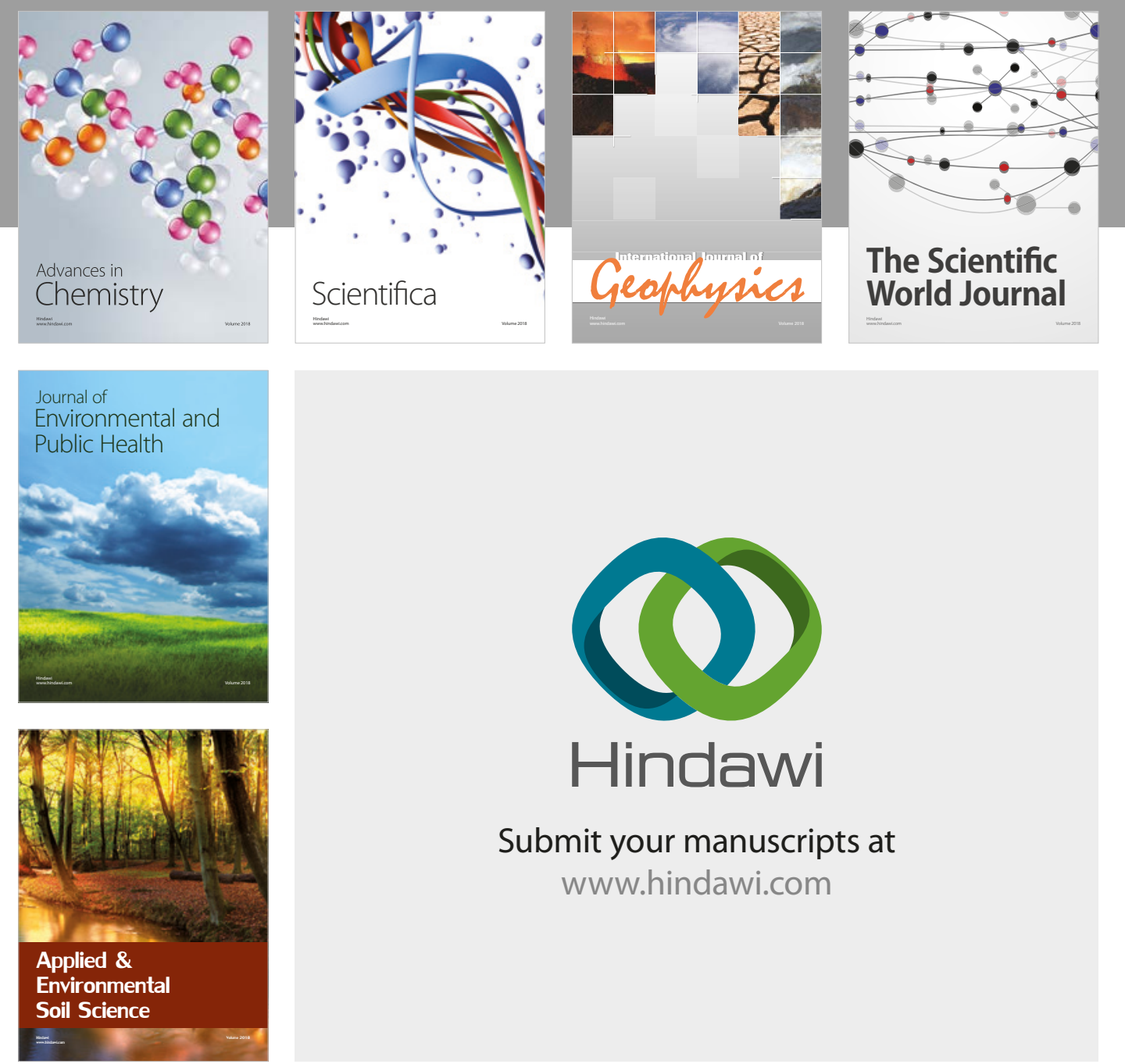

The Scientific

\section{World Journal}
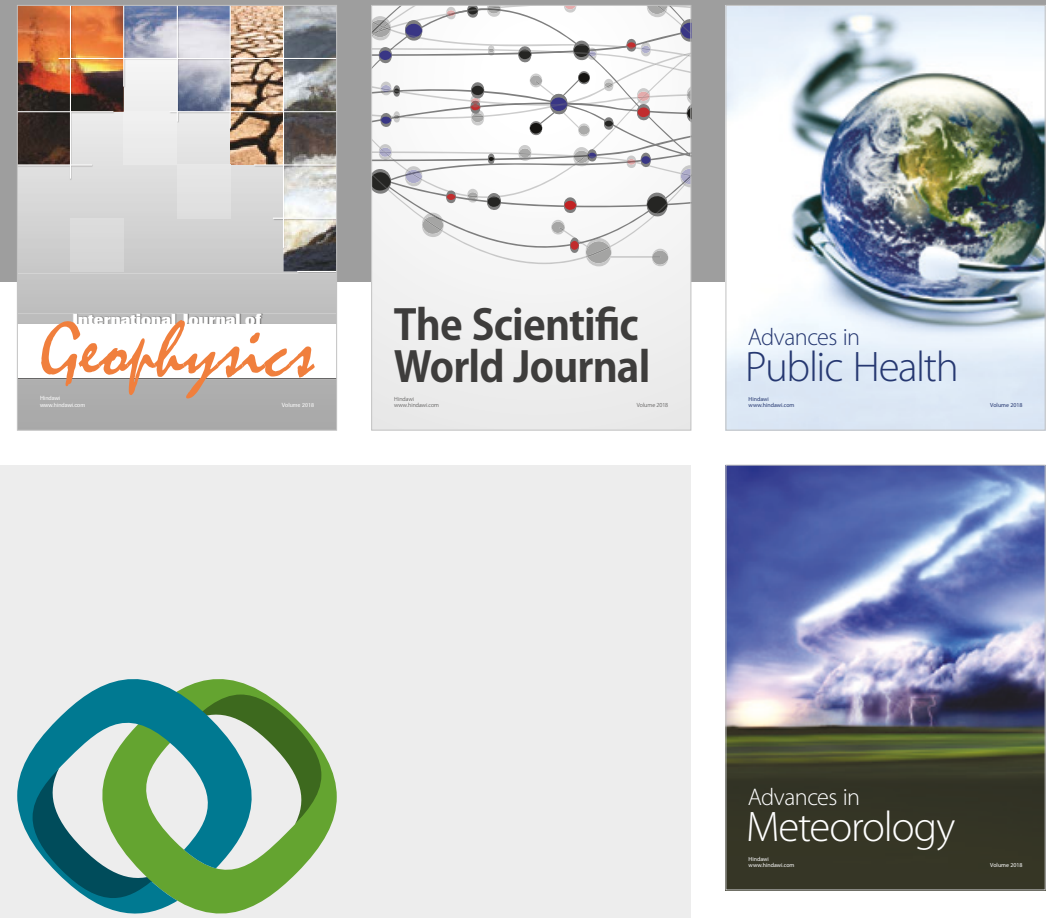

Advan

Public Health

\section{Hindawi}

Submit your manuscripts at

www.hindawi.com
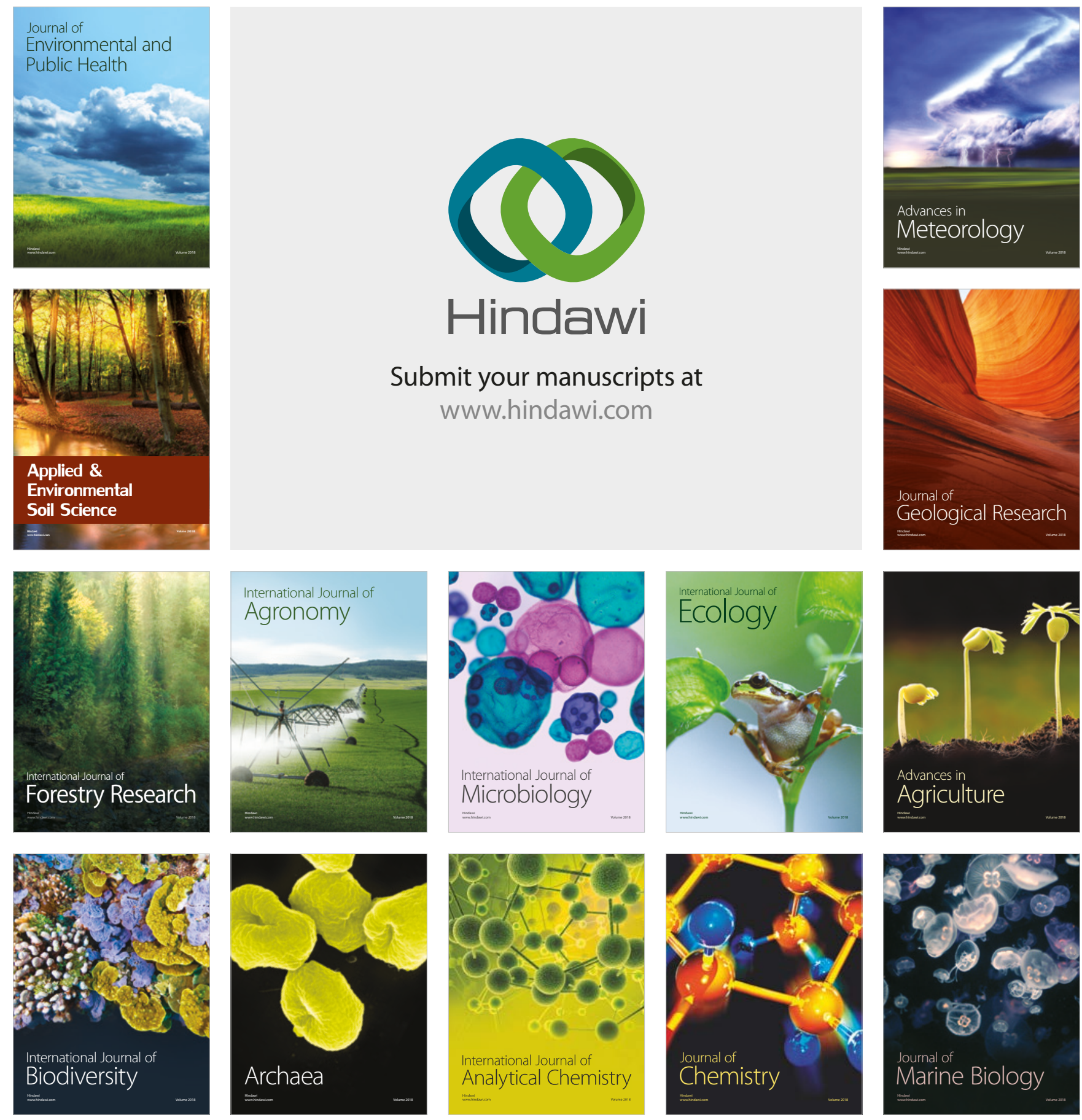